Databases, Revenues, \& Repertory: The French Stage Online, 16801793 - Databases, Revenues, \& Repertory: The French Stage Online, 1680-1793

\title{
An Analysis of Revenues at the Comédie-Française, 1680-1793
}

François Velde

Published on: Oct 07, 2020

DOI: $10.21428 / 671 \mathrm{~d} 579 \mathrm{e} . \mathrm{ae} 978 \mathrm{ffd}$

License: Creative Commons Attribution 4.0 International License (CC-BY 4.0). 


\section{Introduction}

This paper is a preliminary foray into the 17th- and 18th-century archives of the Comédie-Française, the main theatrical venue in 18th-century Paris, which have been recently digitized by the Comédie-Française Registers Project ( $\underline{\mathrm{CFRP}}$ ). I will focus on the economic issues brought up by the archives. The registers studied here $\underline{1}$ are an almost continuous record of the daily performances at the Comédie-Française, containing titles of plays performed, names of actors performing, daily expenses, and receipts broken down by seating category for 34,129 distinct sessions. $\underline{2}$ The reason for keeping these records was simple: actors who had performed were entitled to share the net proceeds. The registers have been known and used by historians of the theater for a long time, $\underline{3}$ and I am not the first to look at them from an economic angle, but the digitization allows much more to be done, since, at this stage, the receipts have been transcribed. I hope that this work will help broaden the appeal of the CFRP. $\underline{4}$ The registers are interesting because of the Comédie-Française's importance in the history of French theater. In addition, once the Comédie-Française is seen as a business, they present an unparalleled record. Few, if any, businesses have lasted as long in the 18th century and rarely have archives been so well preserved. Admittedly the entertainment industry is a particular one, but it is still an industry, and the Comédie-Française was a dominant player, if not quite a monopolist.

I will use the time series of receipts as a starting point. $\underline{5}$ My goal is to understand the evolution of this time series, seeking explanations in outside factors and in the Comédie-Française's own choices. As a business it operated under some constraints, but it had a number of variables under its control: the number of performances, pricing of tickets, and most importantly the choice of works to perform. $\underline{6}$ I will also draw data from the Comédie-Française's main competitors: the Opéra and the Comédie-Italienne, for which archival material is not as rich but still plentiful. $\underline{7}$ Bringing these elements together gives an overall picture of the entertainment business in 18th-century Paris.

The appeal of the registers thus goes beyond pure business history. They can also shed light on how a business reacted to various macroeconomic, in particular monetary, events. Finally, taken as a proxy of spending on entertainment in Paris (and eventually joined with surviving records from the two main competitors) the data in the registers may shed light on income growth in the 18th century. 


\section{Overview of the Comédie-Française}

This section provides basic relevant information about the institution. $\underline{8}$

\subsection{Internal organization and the relation with the State}

The Comédie-Française was born in 1680 of the merger, at Louis XIV's behest, of the two main (and rival) theatrical companies in Paris. Since the 15th century theatrical performances required in principle royal permission, and by the 1650s two companies had been permanently established in Paris, one of which, housed in the Hôtel de Bourgogne, had performed many of the great plays of Corneille and Racine. Molière's success with Louis XIV allowed his company to become the third; two mergers, in 1673 and in 1680 , brought the number back to one, in line with the king's centralizing vision of both the economic and the cultural sphere. Not only were they merged: the new company was given a monopoly on the performance of French-language plays in Paris. $\underline{9}$ Beside the legal monopoly, an important asset of the company was the collection of plays they had performed and owned.

The new company, like its predecessors, was a partnership of actors regulated by a private law contract, modified from time to time. The version that governed most of the period under review was executed in 1687, after the Comédie-Française was required to move and build a new theater, necessitating long-term borrowing by the company as an entity.

Since 1685 the equity was divided in 23 shares, but shares could be divided (i.e., an actor could own a half or a quarter share). The basic principles were as follows. Retiring actors were entitled to an annuity of $1000 \mathrm{~L}$ (since 1681 ; increased to $1200 \mathrm{~L}$ in 1735), a lump-sum of $4400 \mathrm{~L}$ (since 1686), and repayment of the value of their share. Incoming actors were required to pay in the value of their share, the annuity of the actor they were replacing, and the lump-sum payment. $\underline{10}$ While a member of the company, an actor or actress had certain rights in the management of the company and was entitled to a share of the net receipts for performances in which he or she participated. Shares were not tradable, in the sense that an actor held a share only as long as he or she performed and had no say in the choice of the replacement. The nominal value of the equity was set at the total cost of the new theater built in 1689. $\underline{11}$ 
The company set its own internal regulations or by-laws, mostly dealing (in great detail) with the allocation of free tickets (entrées) and with payments to authors. $\frac{12}{2}$ The Comédie-Française was also under the supervision of the First Gentlemen of the King's Bedchamber (Premiers gentilhommes de la Chambre), high-ranking courtiers (usually dukes) who exercised the functions of the Lord Chamberlain (Grand chambellan). Theaters fell under their purview, as part of the King's Revels (Menus Plaisirs). They communicated with the company directly or through the Master of the Revels (Intendant des Menus).

Until the mid-18th century this supervision by the court was relatively light. The Gentlemen issued regulations from 1712, but they mostly reiterated established customs and dealt with internal discipline (actors' attendance at performances, rehearsals, and assemblies) and allocation of roles. One substantive regulation required programs to alternate tragedies and comedies, supposedly because the Comédie-Française tended to perform too few tragedies. $\underline{13}$

Executive tasks were carried out by semainiers, actors who held the position for a week at a time. The business of the company was decided every week at an assembly held on Monday morning. The first order of business was invariably the programming for the following week and the allocation of roles. The assembly also handled submissions of new plays, communications with the court, and generally made all corporate decisions. All decisions were by majority vote, each member having one vote independently of their share. New plays were read in separate assemblies and were either accepted, rejected, or sent back for revision and resubmission with a written report. $\underline{14}$

Over time, growing disorder in the Comédie-Française's finances led to a reorganization. By the 1750s the partnership's debt had doubled to nearly 500,000L. The king bailed out the partnership with a grant of 267,000 L, but at the same time an order in council of 18 June 1757 imposed some accounting discipline, and also tasked the First Gentlemen with establishing new by-laws, which they did on 23 December 1757. 15 A further organizational change in 1766 created an executive committee of six actors, giving more stability to the executive functions hitherto carried out by the three semainiers. $\underline{16}$ The committee was slightly modified in 1780 (see Règlement pour les Comédiens français ordinaires du Roi, Paris: Ballard, 1781).

Although the accounting and finances improved, it's not clear that the ComédieFrançaise's business was controlled more tightly by the court. By and large the theater 
was run by the actors for their own profit, with the First Gentlemen playing a role of arbiter in disputes between actors or with authors. $\frac{17}{}$ Many of the by-laws, as before, dealt with assigning roles and ensuring that actors were held to their commitments. The rules also governed procedures for accepting new plays and the rights paid to the authors.

It is true that the actors received some support from the king. An annuity of $12,000 \mathrm{~L}$ was paid to the actors collectively, a tradition that predated the Comédie-Française's founding and goes back to royal support for the Hôtel de Bourgogne. But one could see it as compensation for the king's option on the company's time, exercised in the form of command performances-although players received a per-diem when they went to court, it was probably below the foregone revenue. More importantly, the support was a fixed sum that did not depend on the company's financial situation. Like the support that the opera received through most of the 19th century, it was a lump-sum and therefore, at the margin, had no effect on the company's decisions, since it did not depend on them.

One could point to the bail-out of 1757 to suggest that State support did, in fact, extend beyond lump-sum payments; a fair point, but this event was literally once-in-acentury, and it does not prove that the actors could depend on, and fully expected, to be bailed out no matter what their actions. The king's reluctance is also plain from his decision to impose stronger governance on the company. $\underline{18}$

\subsection{Industrial organization}

The Comédie-Française was technically a monopoly but in practice faced competition, both in the narrow sense of its genre and in the broader sense as purveyor of entertainment.

Although given by a letter under the king's signet (lettre de cachet), the monopoly on French-language theater proved difficult to defend. Two main competitors were (1) the Comédie-Italienne, in principle authorized to perform Italian-language theater but increasingly devoting itself to performances in French language, and (2) a motley collection of private entrepreneurs who took advantage of the annual fairs of SaintGermain (held very close to the Comédie-Française from Candlemas to Holy Week) and Saint-Laurent (held in the northern suburbs in August and September) constantly to challenge the Comédie-Française's monopoly, eventually leading to the establishment of the Opéra comique. $\frac{19}{19}$ These two competitors merged in 1762 and concentrated henceforth on musical comedy. But theatrical competition resumed again in the 1760s, 
now located mostly on the northeastern boulevards where new theaters (the AmbiguComique, the Variétés amusantes, the Délassements) were tolerated by local authorities despite the protests of the Comédie-Française. But while the troupe tended to fight competitors through courts and appeals to the police authorities, the Opéra monetized its privilege by allowing competitors to perform in exchange for contractual payments. In 1784 the government formally recognized the opera's right to license its monopoly, effectively legalizing the competition, and by 1789 these licensing fees represented $20 \%$ of the Opéra's revenues. Finally the Revolution abolished privileges and in 1791 formally allowed free entry in the entertainment business. $\underline{20}$

In a broader sense the Comédie-Française was competing against the Opéra itself. Established around the same time (1673), its structure was different: rather than a partnership of actors it was a privilege rented out to a private entrepreneur, who salaried his actors. The monopoly progressively became less profitable to the king (and, for a while, the city of Paris) and from 1772 became a net recipient of funds rather than source of income. Nevertheless the Opéra remained until the Revolution a private business. Its shows were obviously of a different nature, and its ticket prices were about double those of the Comédie-Française (whereas the Comédie-Italienne's prices were similar), but the social stratum for which either one was affordable was pretty much the same. In addition, the Comédie-Française also encroached repeatedly on the Opéra's monopoly on sung performances and dances, and even had a small orchestra and ballet troupe on its payroll. $\underline{21}$ We will see several instances of the competition between the two theaters.

\subsection{Calendar}

The term "season" is anachronistic and slightly inaccurate; contrary to the Italian stagione, it does not refer to a part of the year but to the uninterrupted stretch of time (simply called année by the registers) between opening and closing of theaters determined by the religious calendar. I will nevertheless use it to avoid confusion with the calendar year.

The Parisian season, since at least the 17th century, began on the first business day after Easter Week, either a Monday or a Tuesday, $\underline{22}$ and ran until two weeks (one week until 1686) before Easter, the start of Passiontide. The first half was the summer season and the winter season began on November 11 or Martinmas (coincidentally or not, the start of the judicial term of Parlement; judges, lawyers and law students were an important component of the theater's public). The Comédie-Française, as well as 
other theaters, was always closed on the following major religious holidays: Candlemas (Purification), Lady Day (Annonciation), Ascension, Whitsunday (Pentecôte), Corpus Christi (Fête-Dieu), Assumption, Nativity of Mary, All Saints Day, Immaculate Conception, Christmas Eve and Christmas. $\underline{23}$

I will follow the seasonal calendar and, as much as possible, use seasons rather than calendar years.

\section{Annual and weekly patterns}

The Comédie-Française's main theatrical competition, the Opéra, followed the same season and observed the same holidays, but only performed three days of the week in summer (Tuesday, Friday, Sunday) and also on Thursdays from Martinmas to the season closing. At the Comédie-Française, Tuesdays and Fridays were known as petits jours or "off-days." The Comédie-Italienne followed the same calendar and performed nearly every day, like the Comédie-Française.

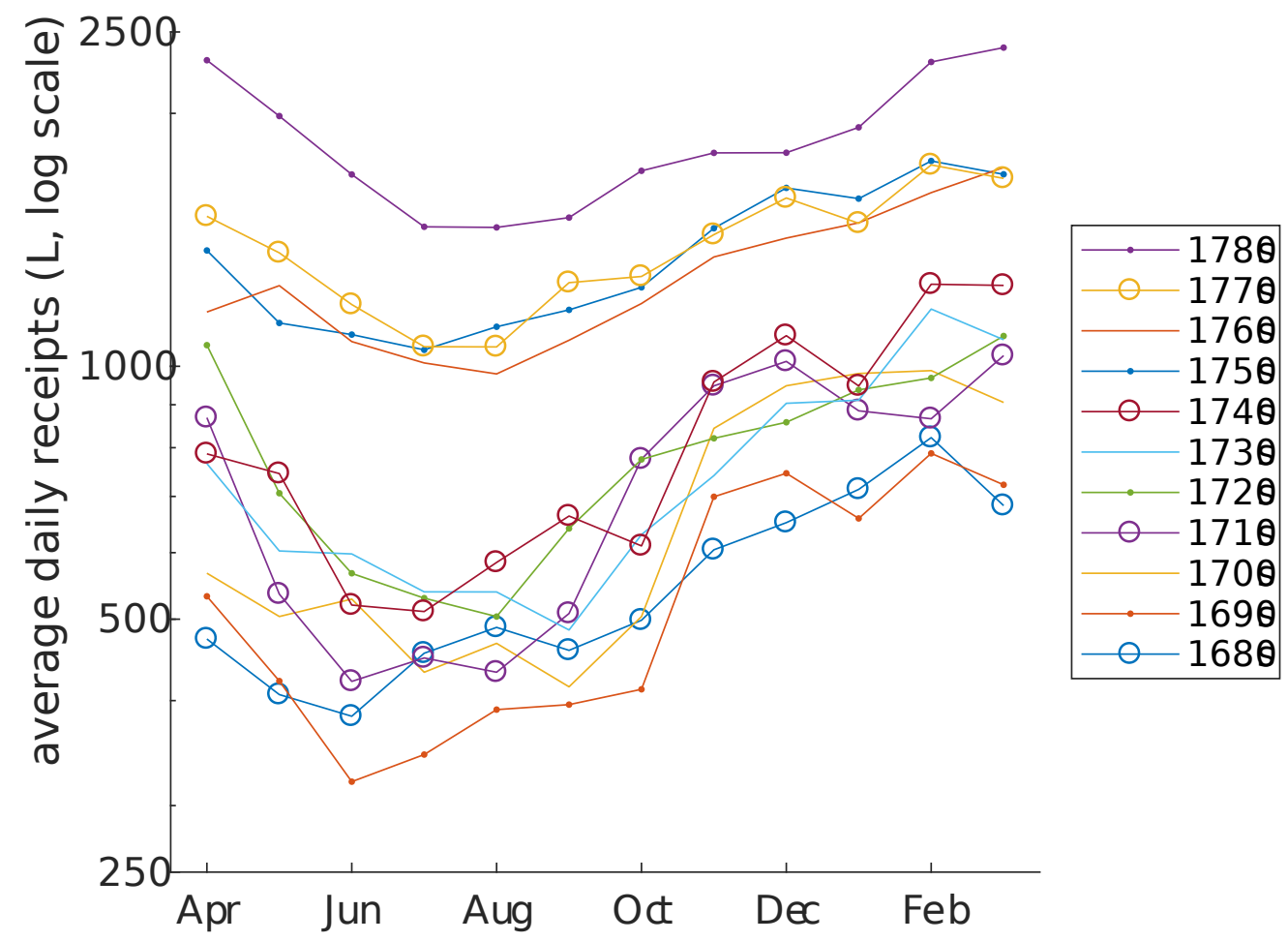




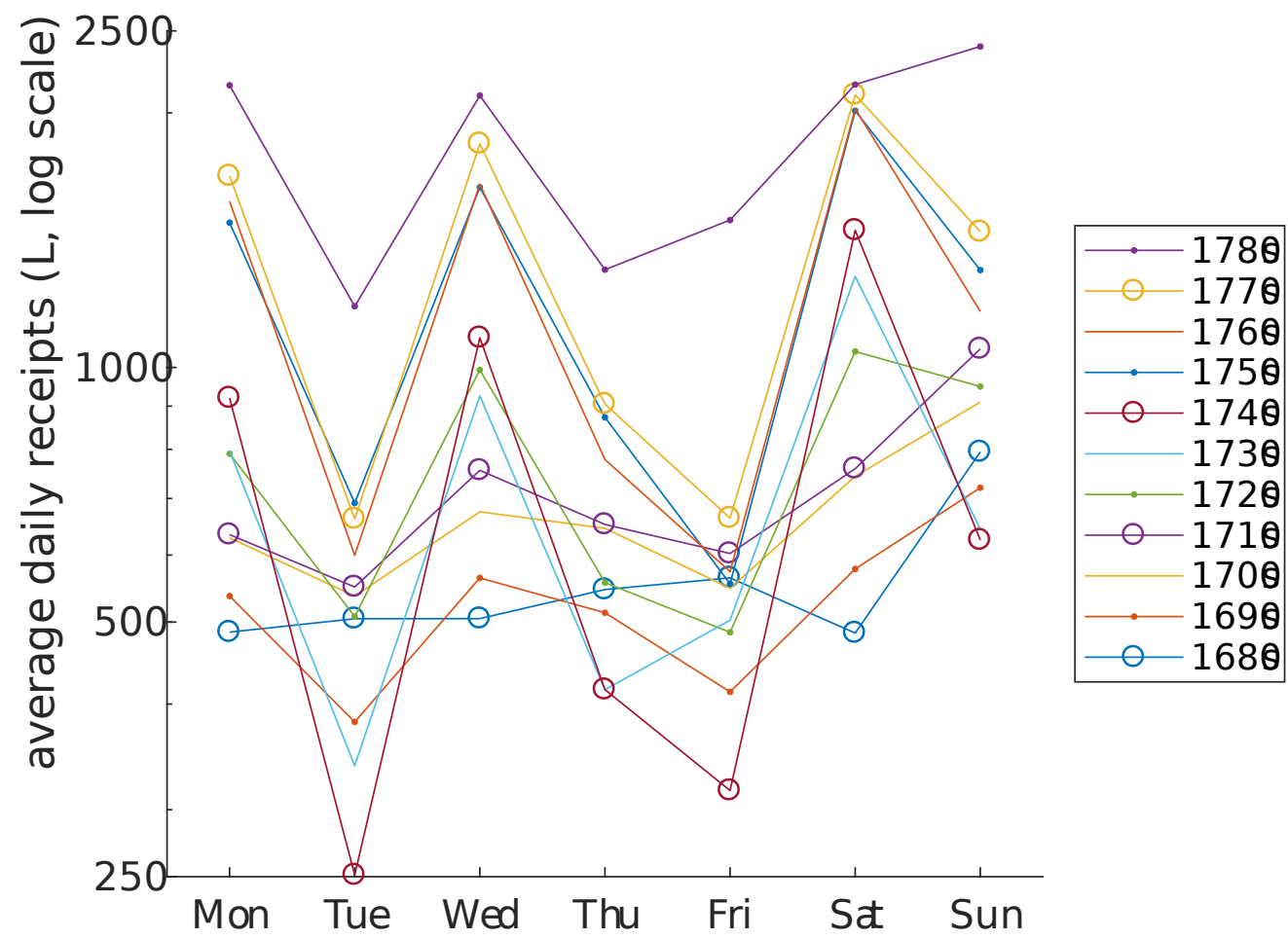

Figure 1. Seasonal patterns in daily revenues: annual (top panel) and weekly (bottom panel), by decade (log scale).

Figure 1 displays the seasonal patterns in revenues, by month and by day of the week. The monthly pattern is visible throughout the century, although it weakens after 1750 . The high season is the winter season (November to April) while the low months are June to August. Henri Lagrave notices this pattern and discusses possible reasons, the most obvious the departure from Paris of the landed clientele to escape the heat and monitor agricultural operations on their estates. $\underline{24}$

The within-week pattern does change markedly over time. In the 1680 s there is no variation within the week, except for the dominance of Sunday. From the 1690s to the 1720s a mild difference develops between Tuesdays and Fridays, while the dominance of Sunday remains. After 1720 the difference between the petits jours (Tuesdays and Fridays) and the other days becomes very stark, while Saturday replaces Sunday as the most profitable. The pattern weakens in the last decade and Sunday becomes again the most successful day. I will return to this pattern after having discussed ticket prices.

Figure 2 shows the patterns in attendance (number of bodies) rather than revenues. The overall picture is not very different. Nevertheless, in terms of attendance the 
attenuation in the annual pattern is sharper: it is much less pronounced after 1750 . The weekly pattern shows that the difference between petits jours and grands jours is not just due to the pricing that I will discuss later.

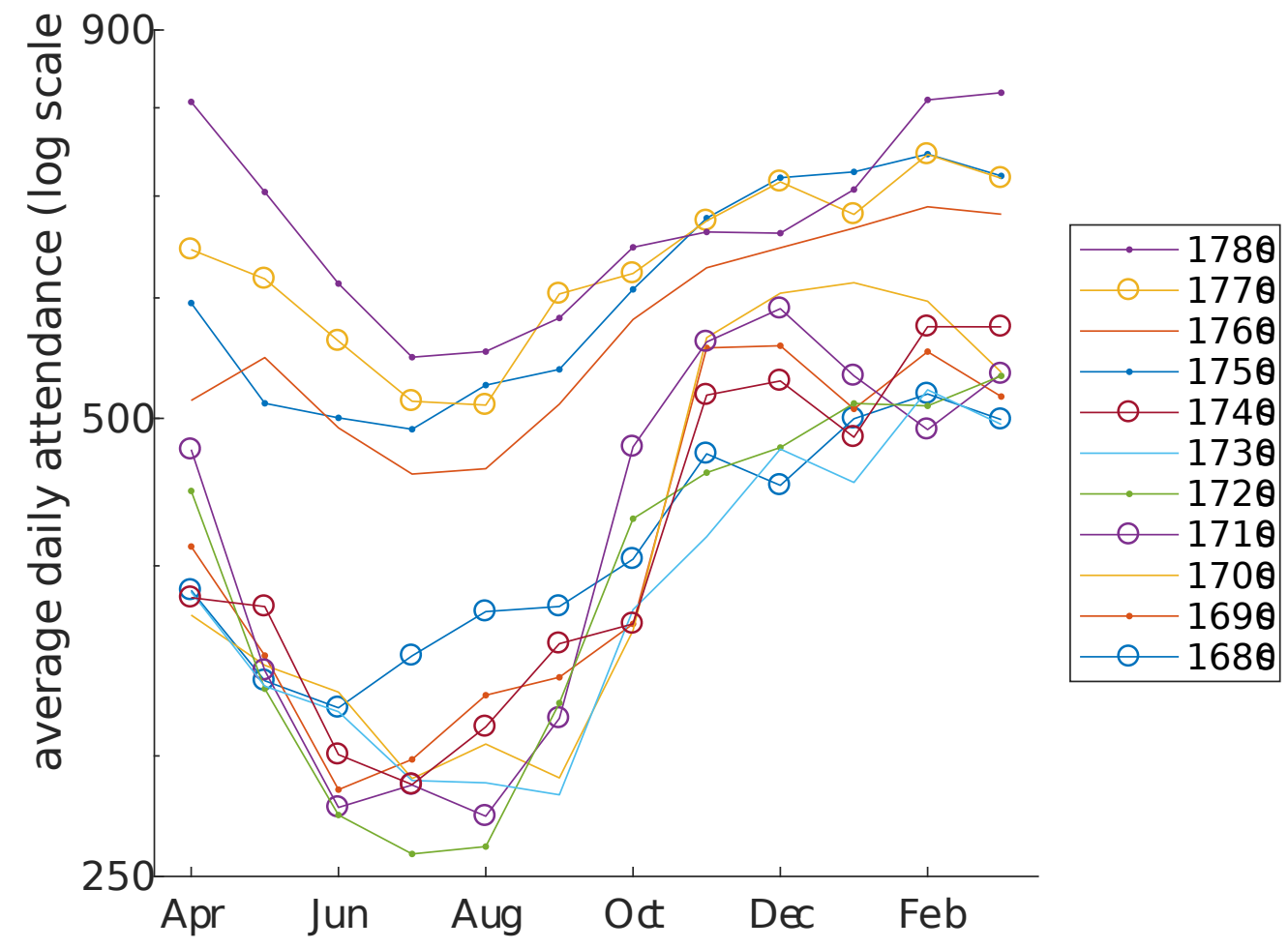




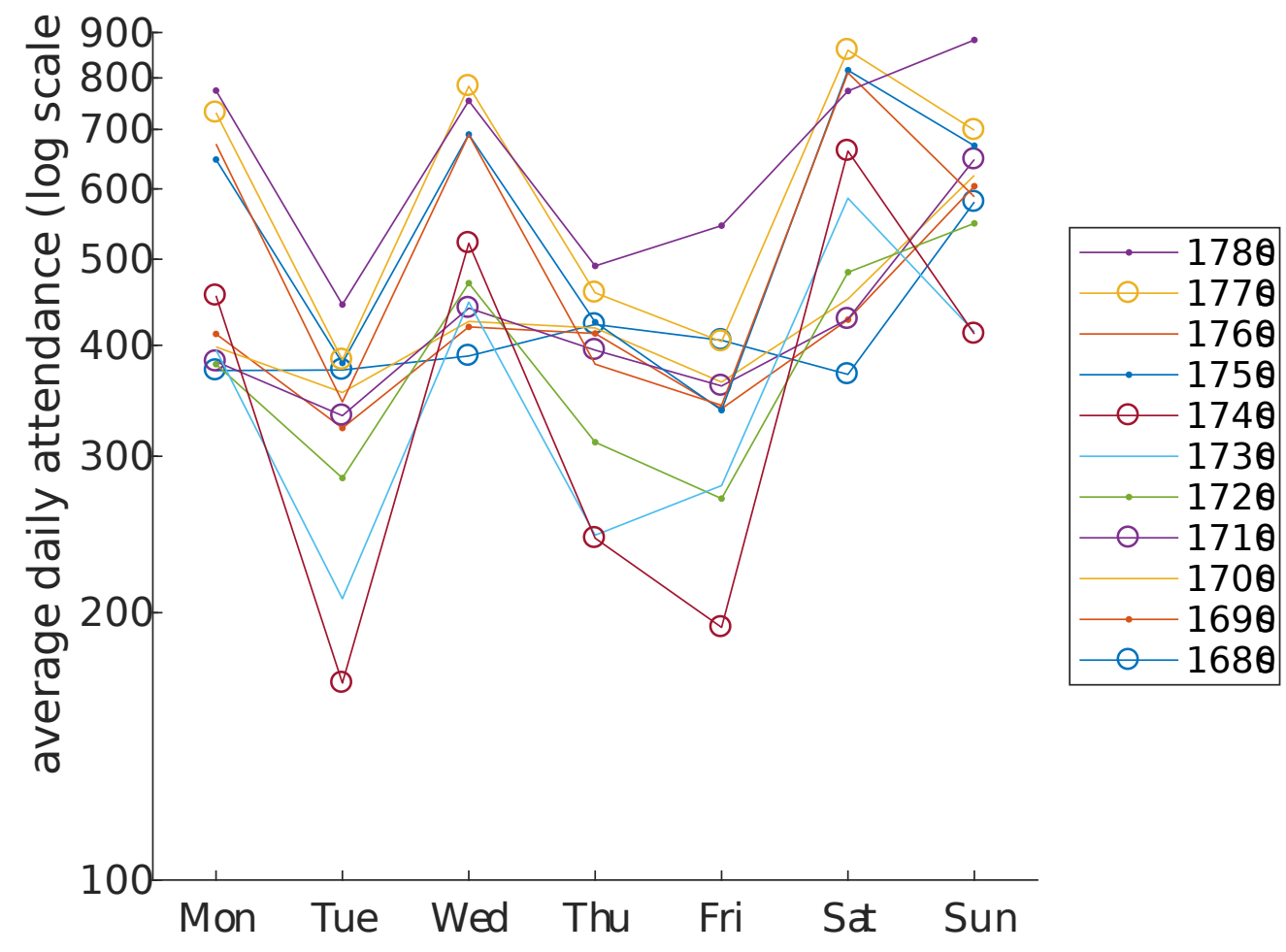

Figure 2. Seasonal patterns in daily attendance: annual (top panel) and weekly (bottom panel), by decade (log scale).

\section{Closures}

After the merger of August 1680 the company ceased to share its venue with the Italiens; thereafter the Comédiens du roi (King's Players) were under an informal, and from 1757 formal, obligation to perform at their regular venue in Paris every working day (excluding the religious holidays listed above). In practice the percentage of closed days out of total working days averaged $9 \%$ and varied for a variety of reasons.

First, the players could be called at will for command performances at court in Versailles or Fontainebleau where the court resided during hunting season. The ensemble was large enough that, in principle, both obligations could be met on the same day. In practice it was sometimes impossible or inconvenient to do so. Hence "court service" was an important reason for closures (about 30\%). These closures occurred almost always (91\%) between October and Passiontide, with a peak in January.

Exceptional religious events (about 5.5\% of closures) were mostly jubilees. $\underline{25}$ Court mourning (about 11\%) varied in length depending on the rank, $\underline{26}$ and tended to 
shorten over time as part of a general trend. $\underline{27}$ Princely births and marriages, peace treaties, and other momentous occasions were marked by a free performance, which is not a closing per se but appears as an absence of revenue in the series. $\underline{28}$

Miscellaneous events (7\%) that led to closures were mostly public celebrations (such as fireworks) for royal births and marriages or peace treaties, which presumably drew spectators away from the theater. Public disturbances were frequent after the start of the Revolution. Among explanations given in the register, one finds weather (excessive heat or cold) theater business (rehearsals, installation of machines, absences of actors), or unexplained lack of spectators.

The rest of the closures (44\%) are unexplained $\underline{29}$ beyond the laconic mention that "on a donné relâche au théâtre." But the timing of these unexplained closures is not random. The vast majority occurred on petits jours (35\% on Tuesdays and $52 \%$ on Fridays), and during the summer half of the season (85\% between Easter and Martinmas, 52\% between July and September). It therefore seems likely that they reflect a choice made by the players not to perform because they could reasonably expect insufficient receipts. 


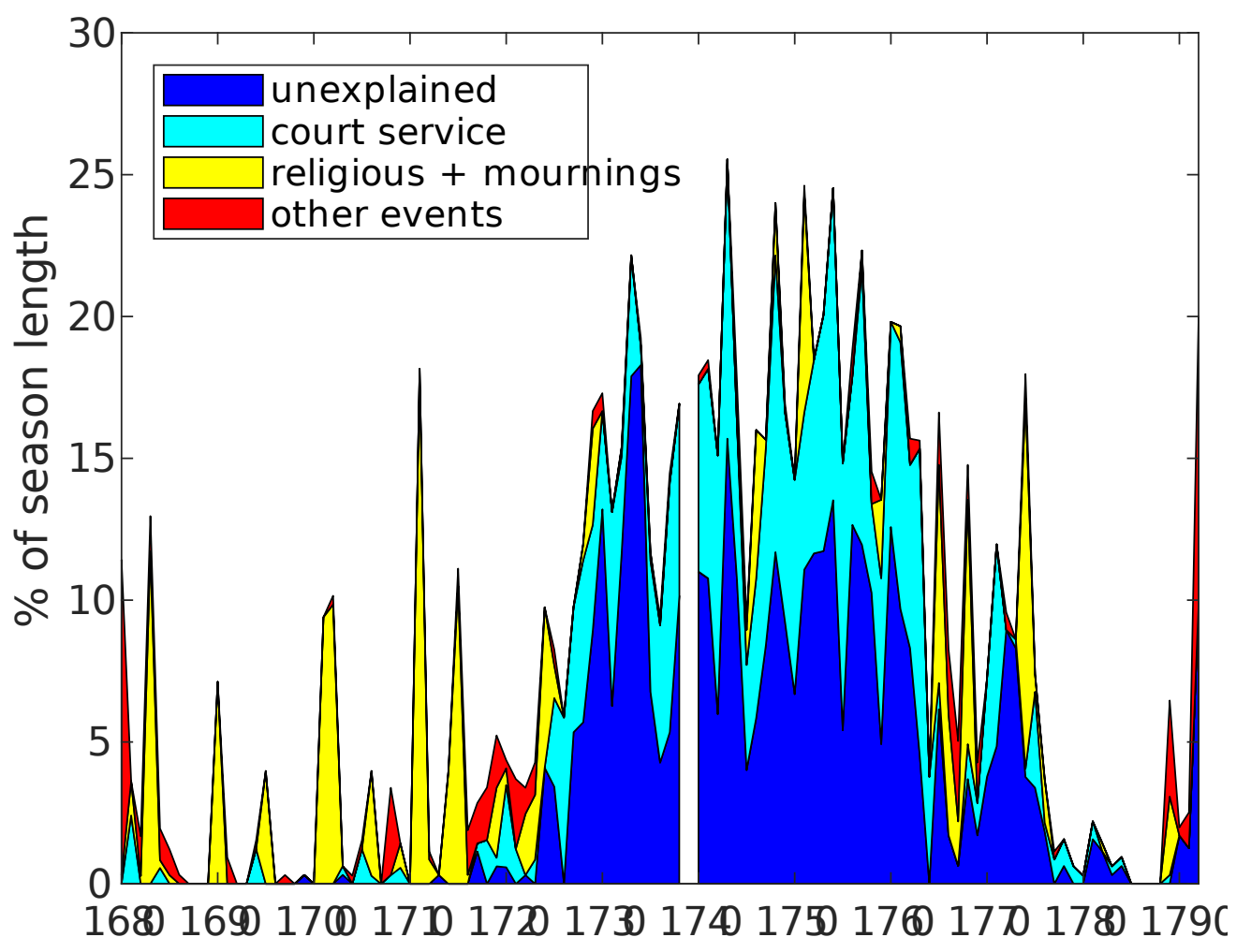

Figure 3. Fraction of non-performance days out of all working days.

Closures varied over the course of time, as shown in Figure 3. Until 1723 they were essentially due to religious occasions and court mourning. From 1724 the total proportion of closures out of the season varies between $10 \%$ and $25 \%$, about half for court service and half unexplained. From 1764 closures fall markedly, and after 1776 they become negligible.

The covariance of unexplained closures and court service between 1724 and 1764 suggests some causation. Actors who went to court were not available to perform the same day in Paris. The company was large enough to handle both obligations, but it may have been unwilling to do so, especially on nights when attendance was likely to be lower. The regulations of 1757 and 1766 specified that, since the plays to be performed at court were known in advance, the company should take care to arrange its schedule so as to meet its obligation. The company apparently chose not to do so for a long period of time. 


\section{Revenues}

The revenues figures I use here add up receipts from ticket sales. As will be explained later, another source of income from the 1750s onward were annual rentals of boxes, but they are available on an annual basis and cannot be meaningfully converted to daily receipts. I also exclude "irregular receipts" which comprise a variety of items, such as late payments on ticket sales that cannot be ascribed to a particular night, occasional bonuses, carry-overs, and other items.

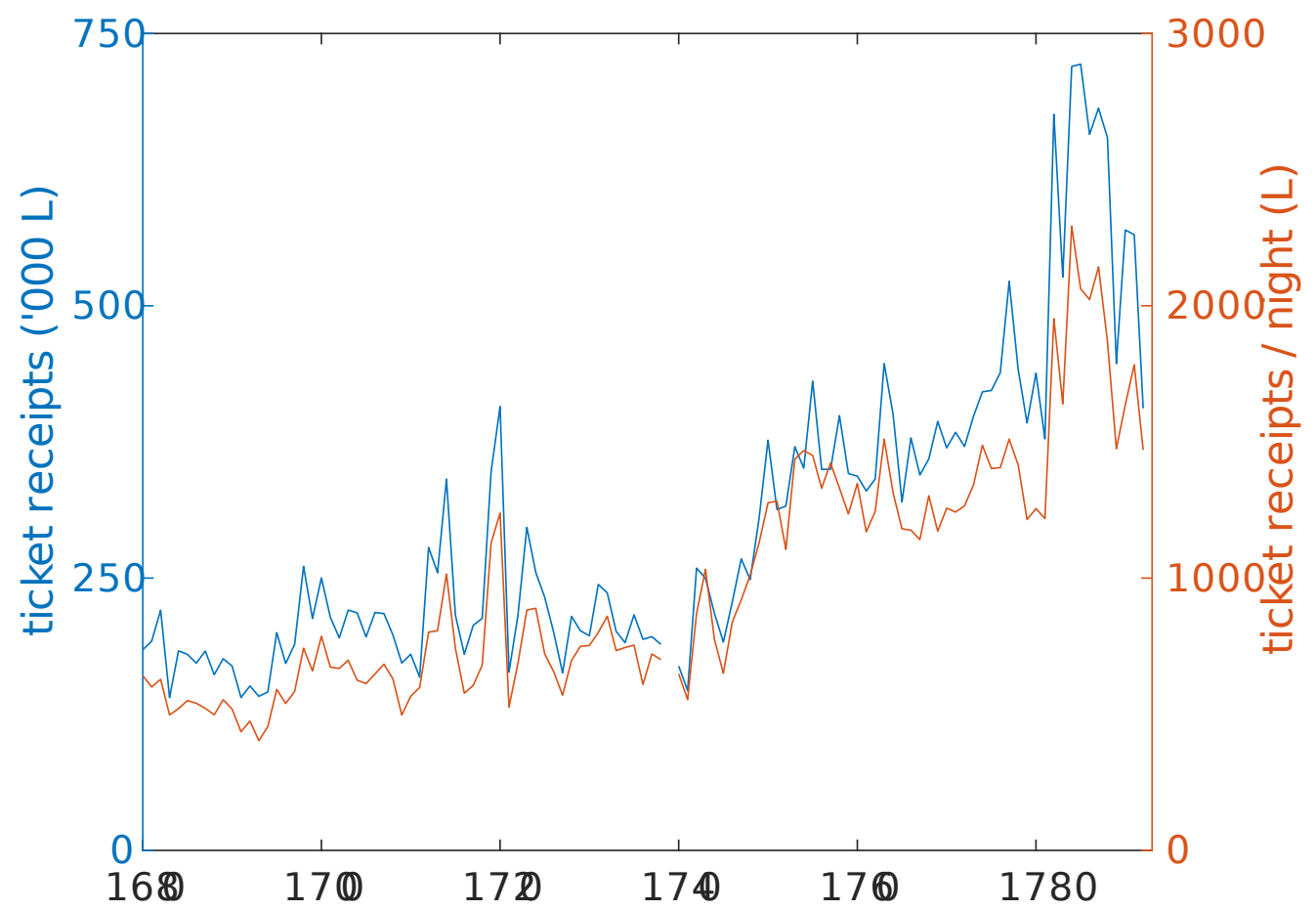

Figure 4. Seasonal revenues (left scale) and revenues per night (right scale) from ticket sales, 1680-1792.

\subsection{Basic Facts}

The starting point of my investigation is Figure 4, plotting revenues from ticket sales on a season basis.

The stylized description of this graph is as follows. Two periods can be distinguished, with the break around the late 1740s (we may arbitrarily use the peace of Aachen as chronological anchor). 
In the first part, revenues are relatively flat, though they display some year-to-year variations. Particularly noticeable are the boom in $1712-14$, followed by a return to normal levels in 1715-16 (years of economic difficulties); the boom of 1719-20 presumably associated with the expansionary phase of the Mississippi bubble; the peak of 1723, also a period of economic expansion, followed by the severe recession of 172426; and the crisis of 1740-41. The troughs, however, are not as marked as the peaks, suggesting that the impact of booms and recessions was not symmetrical. Surprisingly, wars show little effect. Regressing the detrended log of revenues on a wartime dummy yields a statistically significant coefficient but the magnitude is small (a year of war subtracts $7 \%$ of revenues on average), and the dummy explains only $5 \%$ of the variation in revenues from a linear trend. $\underline{30}$

After 1749, any year is better than the best years of the first period. The last years of the Old Regime are particularly prosperous, coinciding with the move to the newly built theater and (as we shall see below) an increase in prices. But, as I discuss later, the new theater did not have more seats than the previous one, and only the pit prices were increased. In any case, having a larger theater or charging more does not alone result in more revenues: the public has to be willing to fill that theater and pay those prices.

Comparing the two lines shows that capacity utilization (that is, the number of performances per season) explains some of the variation, in particular some of the increase after 1750 , but not a lot.

The increase in revenues shown in Figure 4 understates the demand, because they exclude annual box rentals, a practice begun in 1753. $\underline{31}$ One financial advantage, aside from insuring stable revenues for the year, was that the poor's tax (see below) was only levied on daily receipts. Figure 5 shows that the practice, which had begun in the 1720 s at the Opéra, soon accounted for a substantial portion of revenues, as well at the Comédie-Italienne which followed suit in 1760. $\underline{32}$ Therefore the growth in ticket revenues understates total receipts. I will set aside the box rental income for now. 


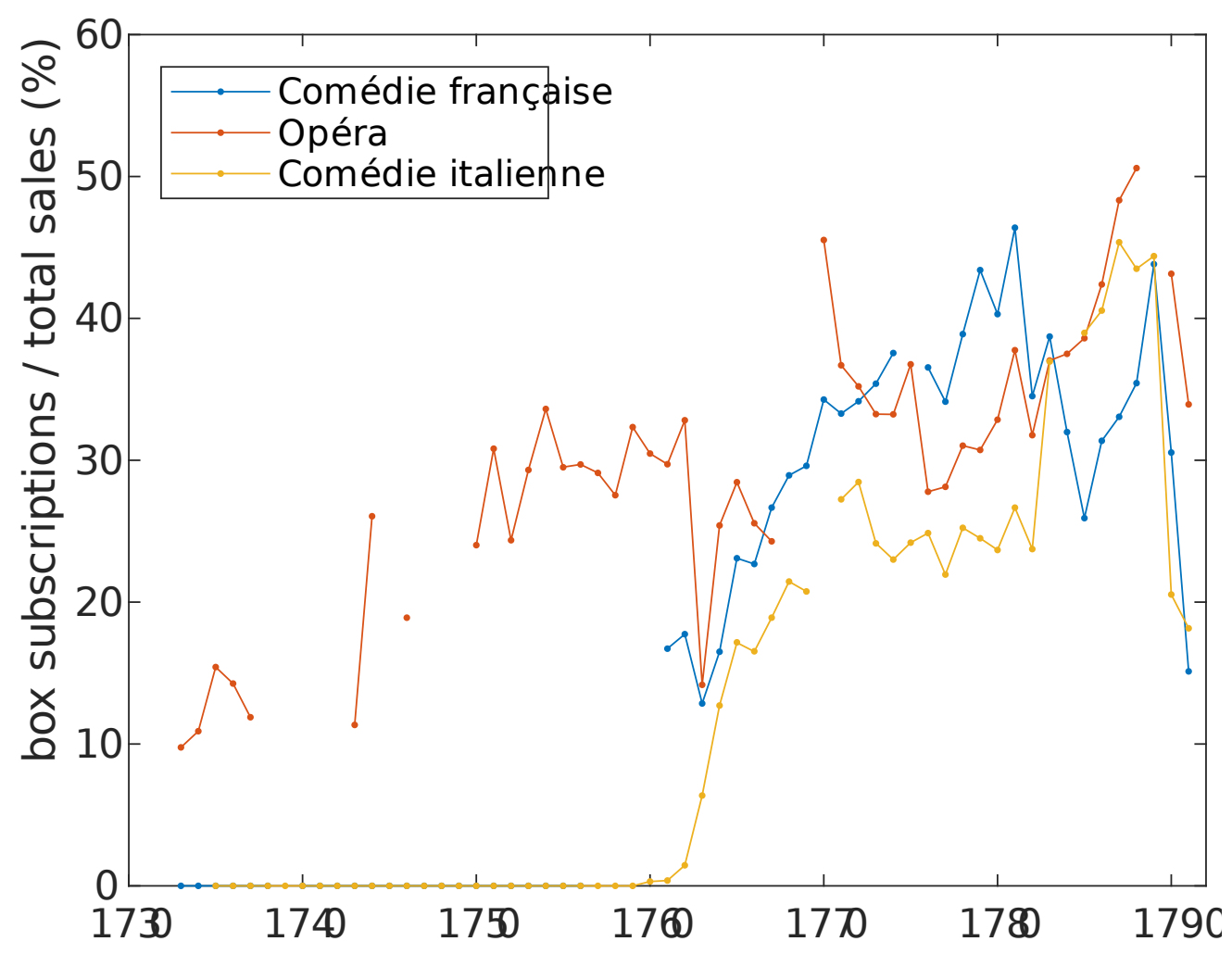

Figure 5. Fraction of total sales from box subscriptions, 1733-1791.

\subsection{The approach}

I would like to use Figure 4 as a thread through the Comédie-Française's (pre-1793) history. The starting point is that it was run as a business operating in a marketplace. Did conditions in the marketplace change, or did the Comédie-Française's practices change, or a combination?

\section{Conditions outside the Comédie-Française}

\subsection{Other theaters}

Was the revenue growth peculiar to the Comédie-Française?

Figure 6 shows ticket sales at the three main Paris theaters. $\underline{33}$ Although the exact timing and path differ, all three theaters display the same pattern. The first half of the 
century shows similar variations but no trend. After the late 1740s all see the same increase up to the early 1790s. Interestingly all three suffer from the events of 1789 but rebound sharply in the last two seasons of the monarchy.

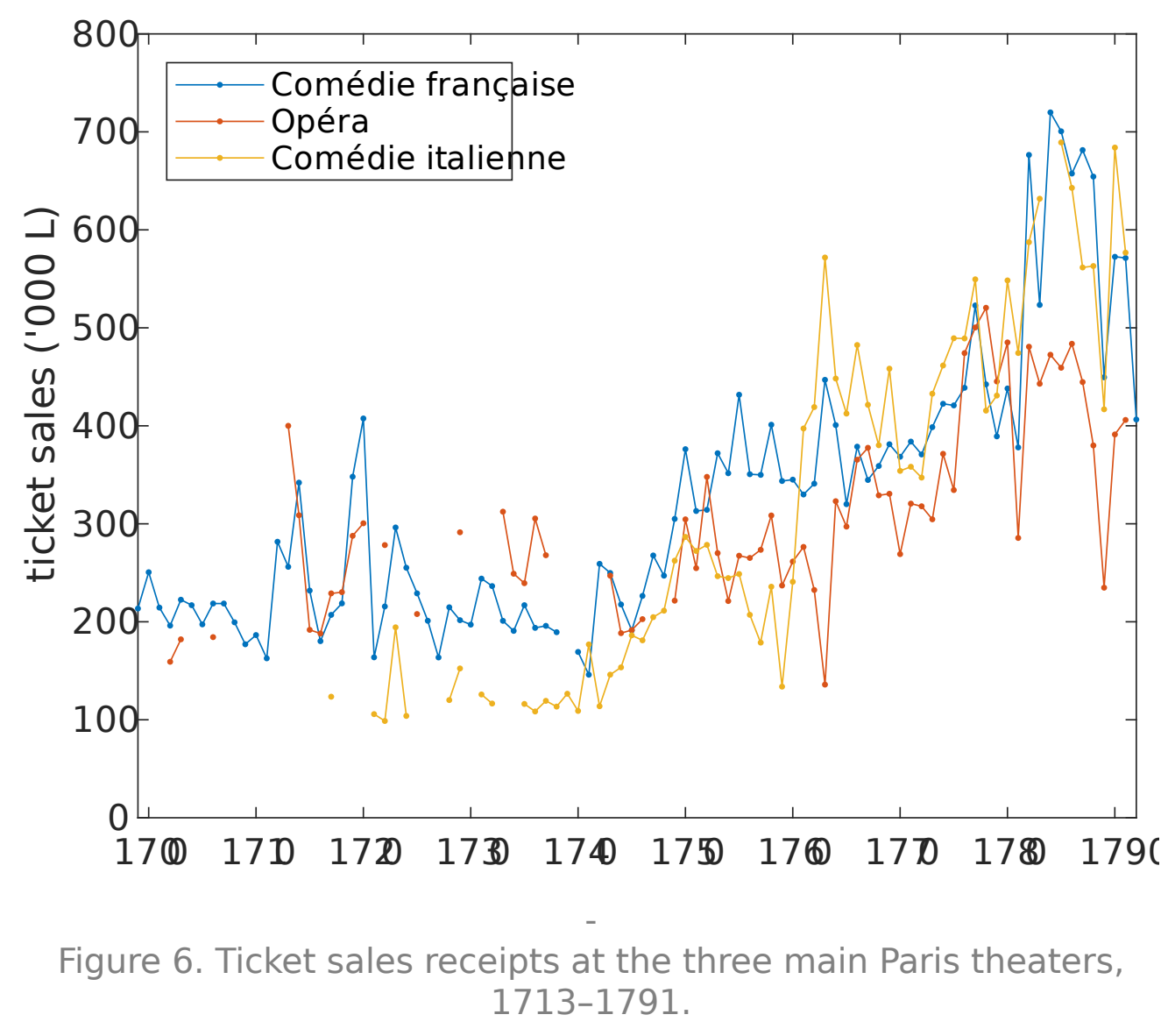

Figure 7 provides the broadest possible view of Parisian entertainment by including box rental revenues for the "big three" and by including other venues. To get revenues data for the latter, I rely on tax income. As I explain later in the section on ticket prices, a tax was levied on the Comédie-Française and the Opéra to finance hospitals for the sick and poor since 1699. In 1713 the tax was extended to all public entertainment venues. Archival records $\underline{34}$ allow me to infer the revenues at the fairs of Saint-Laurent and Saint-Germain (which, as mentioned earlier, operated only a few weeks in the year). Note the sharp rise at the fairs between 1752 and 1762: this corresponds most likely to the Opéra comique, whose merger with the ComédieItalienne in 1762 explains the sharp rise that year in Figure 7. In addition, from 1773 the hospitals started collecting from entertainers on the boulevards (Danseurs du Roi, Ambigu-comique, Variétés amusantes, etc) and from 1785 from a plethora of venues. 
The tax was mostly collected via the abonnement system, that is, a flat fee was negotiated: so it should be taken as a general estimate rather than a precise one.

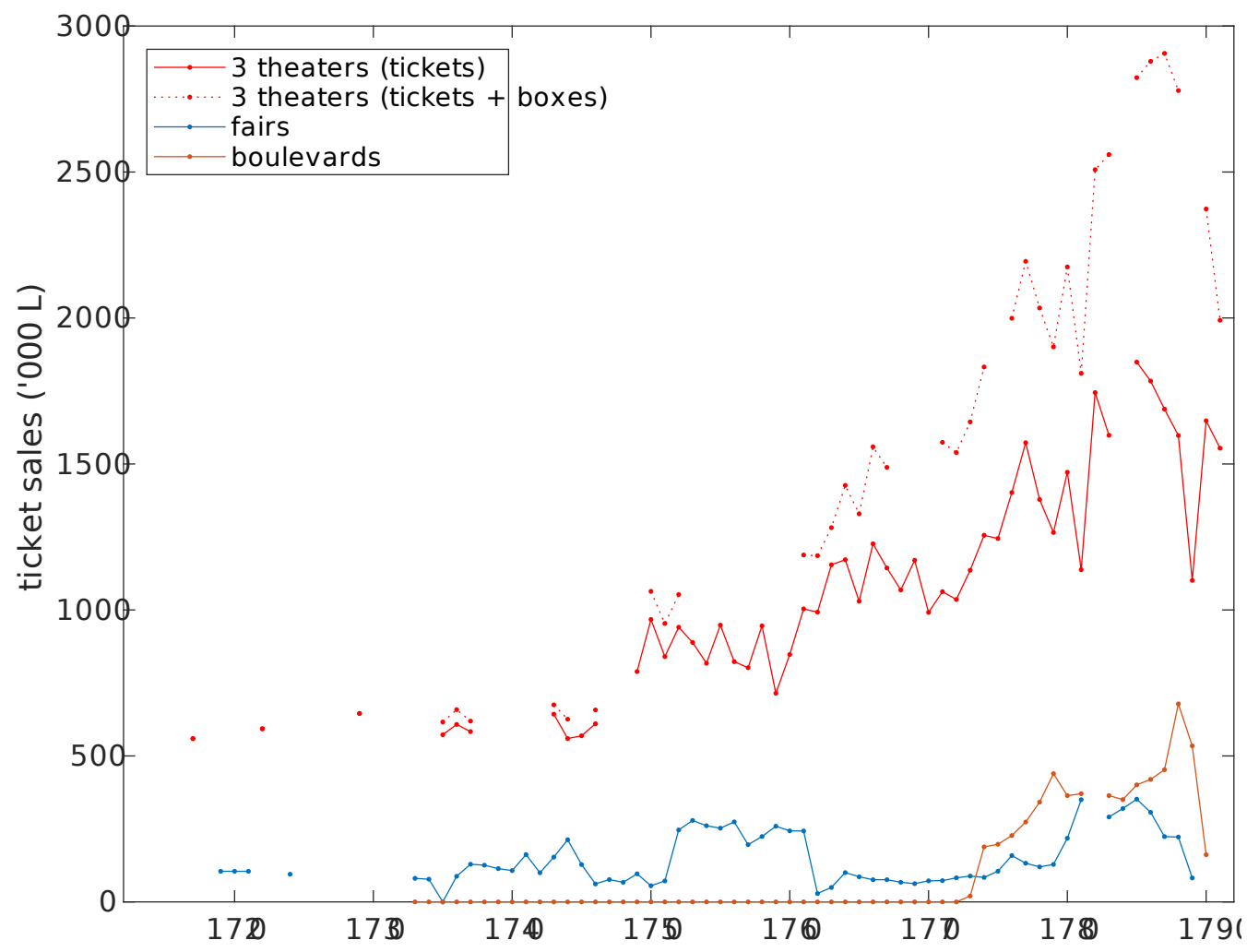

Figure 7. Revenues at the all Paris theaters, 1713-1791.

Figure 7 confirms that theater revenues in all venues displayed little or no trend before 1750, hovering around $0.7 \mathrm{~m}$ livres. From 1750 the three theaters see their revenues grow, both ticket sales and box rentals. Revenues also rise at the fairs, and more markedly in the competitive fringe of the boulevards. In 1788 total spending on theaters reaches $3.5 \mathrm{~m}$, a five-fold increase in forty years. The figure also shows that the "big three" still accounted for $75 \%$ of revenues in 1788, and that while ticket sales recovered from the events during the 1789-90 season box rentals plunged: by the 1791-92 season ticket sales were only 3\% lower than in 1788-89, but box rentals were down $62 \%$. Not surprisingly, the impact of the Revolution on theater-going was not the same across social categories.

Within this broader context, the market share of the Comédie-Française is shown in Figure 8. It is both highly variable in the short term and stable in the long term. Indeed, knowing the five-fold increase in theater revenues from 1750 to 1788 , the long- 
term stability suggests that the Comédie-Française was reasonably successful in maintaining its market share, while the short-term volatility suggests that this was no easy task.

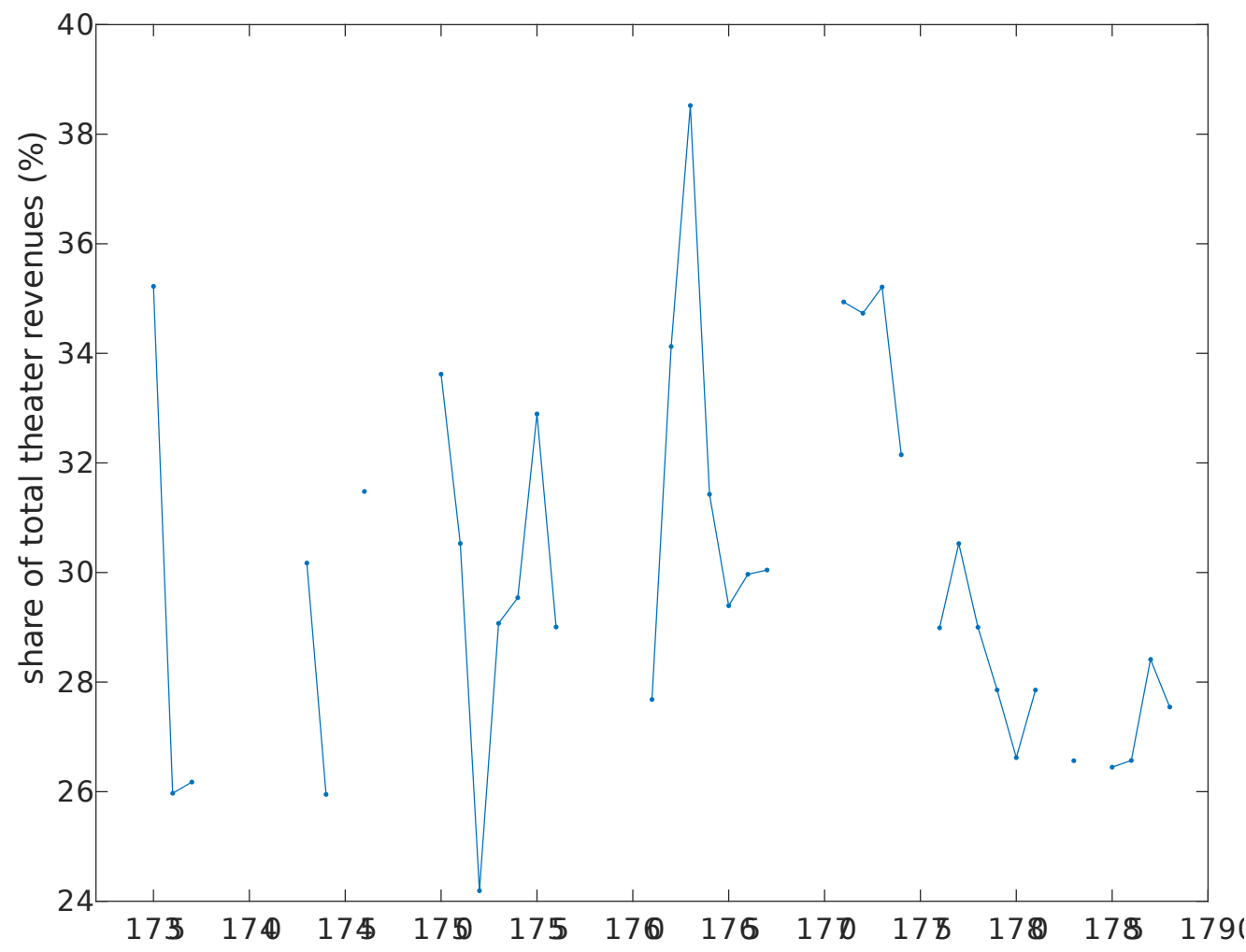

Figure 8. Share of Comédie-Française revenues (including box rentals) in total Paris revenues.

\subsection{Inflation}

A question that comes to mind when examining a long-term time series expressed in nominal terms is: should it be adjusted for inflation? In other words, is the observed rise an artifact of inflation?

We lack a reliable price index for the period, in part because of the monetary manipulations of 1690-1726 described above. More generally, while price series are readily abundant for commodities traded on central markets, especially grain, we have less data for other commodities, goods, and services. We also lack detailed information on consumption baskets, or generally what quantity-based weights should be used to weight the price series to form an index. 
That said, I use the price indices of Hoffman et al., who compute an index with weights corresponding to an urban worker and to a "rentier," in the latter case accounting for the purchases of the services of servants. $\underline{35}$

In addition, I have also computed an index of grain prices. The price series are quarterly prices of wheat, oats, barley, and rye in seven regional markets around Paris. The method used to compute a common index essentially weighs them according to their volatility. The resulting series displays major spikes during grain shortages, but also a general profile that actually broadly matches the revenues series.

Figure 9 compares the revenues figure with the two decade-based indices from (Hoffman et al.) and the index of grain prices.

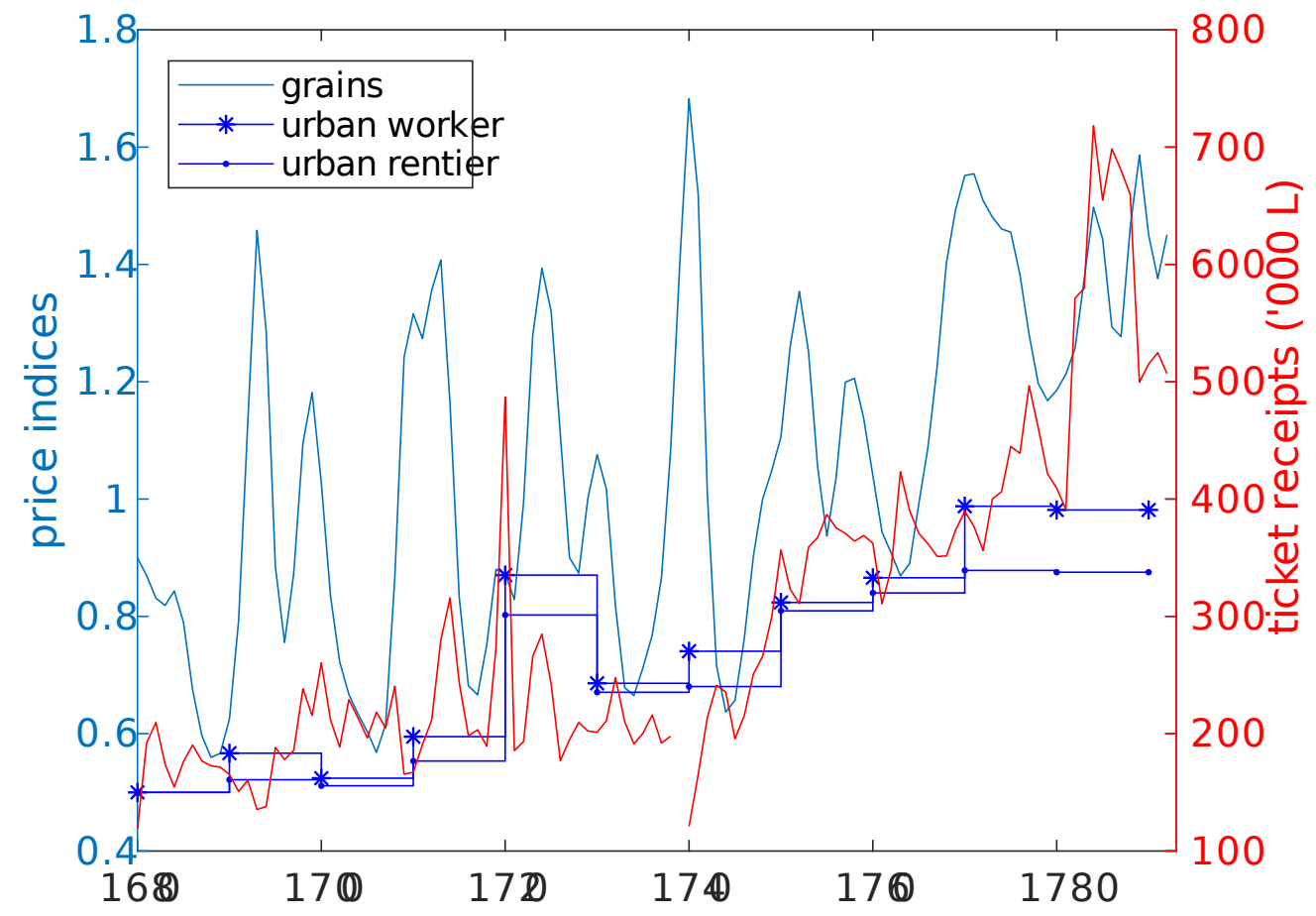

Figure 9. Consumer price indices and index of grain prices around Paris (left scale) and total revenues from ticket sales at the Comédie-Française (right scale).

\subsection{Incomes}

Broadly speaking the rise in revenues seems to correspond to some degree to a rise in prices in the second half of the 18th century, particularly marked for grain prices. Yet 
the increase in ticket prices comes just as the abrupt rise in revenues ends, and its magnitude (about 20-25\%) does not account alone for the rise in revenues. Nor is there an immediate connection between grain prices and revenues at the ComédieFrançaise.

A more promising hypothesis is the redistributive effect of inflation, especially grain inflation and the rise in urban and rural land rents. $\underline{36}$ Some theater-goers belonged to the landed classes, most likely to benefit from this rise in prices, while others (law professionals, skilled artisans) would benefit indirectly to the extent that they serviced the former. It is thus not necessarily a general rise in incomes or prices that would account for rising expenditures on theater, but a rise in incomes of certain social categories.

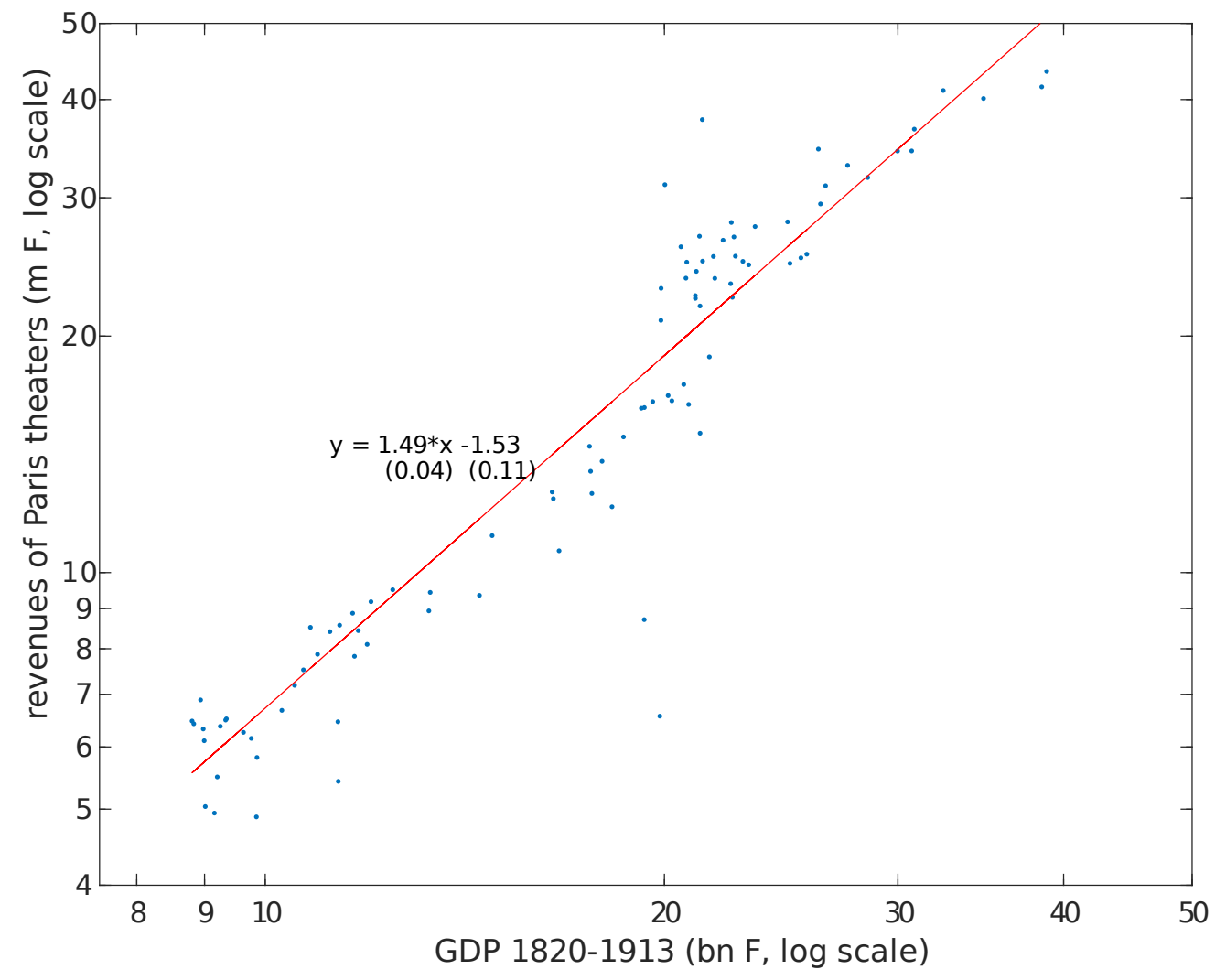

Figure 10. Nominal GDP and theater revenues in Paris, 1820-1913.

The 19th century (for which we have better data) shows a strong relation between national income (GDP) and expenditures on live entertainment in Paris. $\underline{37}$ Figure 10 shows a strong relation between the two. If the years 1831-32 and 1848-49 (years of 
political unrest in Paris) are removed, the estimated relationship is tight, and yields an elasticity of 1.8. It therefore seems reasonable to suppose that the general increase in expenditures on the Comédie-Française and its expenditures reflects a rise in incomes in Paris. Unfortunately we have little in the way of data to confirm this hypothesis.

\section{Foreign trade}

One of the rare data series we have for eighteenth-century France are import and export statistics, available from 1716 to 1780 and broken down by countries. Table 1 shows the correlation of Comédie-Française revenues with the countries for which data is available for the longest period. There is a weak correlation with total trade, both imports and exports, but no clear pattern emerges country by country. The strongest correlation is with SavoyPiedmont, but that is also the country which is least affected by wars in a period in which trade is generally very sensitive to war. These results are presented for the sake of thoroughness, and I don't think too much can be made of it.

\section{Within the Comédie- Française: prices and quantities}

\begin{tabular}{lrr}
\hline correlation with: & & \\
& imports & exports \\
\hline Germany & 0.28 & -0.17 \\
Great Britain & 0.05 & 0.25 \\
Spain & 0.01 & 0.35 \\
Austrian Netherlands & 0.10 & 0.40 \\
Netherlands & 0.06 & 0.30 \\
Italy & 0.01 & 0.01 \\
Levant & 0.18 & -0.05 \\
North & 0.23 & 0.12 \\
Portugal & 0.12 & -0.27 \\
Savoy-Piedmont & 0.33 & 0.75 \\
Switzerland & -0.14 & -0.17 \\
French colonies & 0.16 & 0.09 \\
Total & 0.24 & 0.30 \\
\hline
\end{tabular}

Table 1. Correlation of ComédieFrançaise revenues (annual, calendar basis) with trade statistics by country, 1716-80 (1739 and 1740 excluded). Linear trends are removed from all series. Source for trade data: Ruggiero Romano,

“Documenti e prime considerazioni intorno alla 'balance du commerce' della Francia dal 1716 al 1780," in Studi in onore di Armando Sapori (Milan: Istituto Editoriale Cisalpino, 1957), 1267-1300, corrected with AN F/12/1834A.

Having compared revenues with conditions outside the Comédie-

Française, it is time to look at the revenues as a product of prices times quantities, and determine if either or both changed. I first review the different venues of the ComédieFrançaise. Then, before examining prices, we have to delve deeper into the French monetary system of the time, whose features will turn out to be very useful in 
explaining pricing behavior at the Comédie-Française. I then examine attendance figures.

\subsection{Venues}

A preliminary question is the seating capacity at the Comédie-Française.

There were four regular venues $\underline{38}$ in the period under consideration:

1. the Hôtel Guénégaud (1680-1689), built in a former palm game court;

2. a theater built anew for the company inside another palm game court in the rue des Fossés Saint-Germain (now rue de l'Ancienne Comédie) (1689-1770), until its derelict condition led to the construction of a new, free-standing theater;

3. the Théâtre des Tuileries, which had temporarily housed the Opéra from 1764 to 1770, also served as a temporary home of the Comédie-Française during the construction (1770-1782);

4. the new Théâtre-Français (after 1782), an elegant free-standing building (now called Théâtre de l'Odéon).

The first two are somewhat less documented, especially the first, but they shared the following characteristics. There were seating benches on the stage, on both sides of the performers, and also in the orchestra pit. $\underline{39}$ The rest of the main floor, the parterre (pit), was standing room only. Behind the pit were rows of straight benches (the parquet) and at the back of the room semi-circular benches (the amphithéâtre). Boxes (loges) were arrayed on three levels (the third level had benches until the 1740s). Some boxes overhanging the seats on stage were called balcons. Stage seats were only removed in 1759 . 


\begin{tabular}{|c|c|c|c|c|}
\hline & $1680-1689$ & $1689-1770$ & $1770-82$ & $1782-93$ \\
\hline parterre & & $550-600$ & 600 & 500 \\
\hline amphithéâtre & & 130 & 140 & 120 \\
\hline orchestre & & 40 & & 200 \\
\hline parque & & & 120 & \\
\hline théâtre* & & 140 & & \\
\hline loges RdC +4es & & & 100 & 358 \\
\hline les loges, balcons & & 196 & 264 & 280 \\
\hline 2es loges & & 200 & 224 & 166 \\
\hline 3es loges & & 200 & 166 & 138 \\
\hline amphithéâtre 3es & & & 124 & 300 \\
\hline Total & & 1500 & 1738 & 2062 \\
\hline highestattendarce & 1123 & 1592 & 1373 & 1983 \\
\hline
\end{tabular}

Table 2. Capacity of the venues. Note: seats on the stage were removed in 1759.

Highest attendance means ticket and nightly box rentals but does not include annual box rentals.

Sources: Henri Lagrave, Le Public et le théâtre à Paris de 1715 à 1750

(Paris: Klincksieck, 1972), 81, and Édouard Lepan, Histoire de l'établissement des théâtres en France (Paris: Prechet, 1807), 35.

The Tuileries theater and the new theater of 1782 were larger, having two additional levels of boxes, and from 1782 the pit featured benches. Table 2 shows estimates of the seating capacity, as well as the maximum recorded ticket sales in the register, which broadly confirm the estimates, except for the Tuileries (1770-82). Here the detailed estimate comes from an archival document dating probably from the late 1770s, but it seems problematic as I will discuss further in the next section.

\subsection{Monetary background}

The monetary system of the Old Regime was, superficially, quite simple. Outside one exceptional period discussed below the monetary instruments were gold and silver coins, with some low-alloy silver (billon) or copper coinage for the smallest denominations. The main gold coin was the louis d'or, $22 \mathrm{k}$ gold, weighing $6.75 \mathrm{~g}$ until 1709 , varying several times thereafter, then $8.16 \mathrm{~g}$ from 1726 to 1785 and $7.65 \mathrm{~g}$ from 
1785. The main silver coin was the écu, $91.7 \%$ silver, weighing $27.5 \mathrm{~g}$ until 1709 , varying also until 1726, and $29.5 \mathrm{~g}$ from $1726 . \underline{40}$ The characteristics of coins: weight, fineness, design, were set by royal edict registered in Parlement and the Cour des Monnaies.

The unit of account was the livre (the word franc was occasionally used as a synonym), divided in 20 sous or 240 deniers. The coins never bore any face value. Coins' values in terms of the unit of account were set by the original edict that defined their characteristics, but could be altered overnight by order in council (arrêt du conseil). The value of coins, as well as their metallic content, was generally stable before 1690 and after 1726, $\underline{41}$ but the range of time covered by the registers includes the troubled episode of reformations. Variations in the face values of gold and silver coins are summarized in Appendix 1 and illustrated in Figure 11, which plots an index of the number of livres for a constant weight of silver.

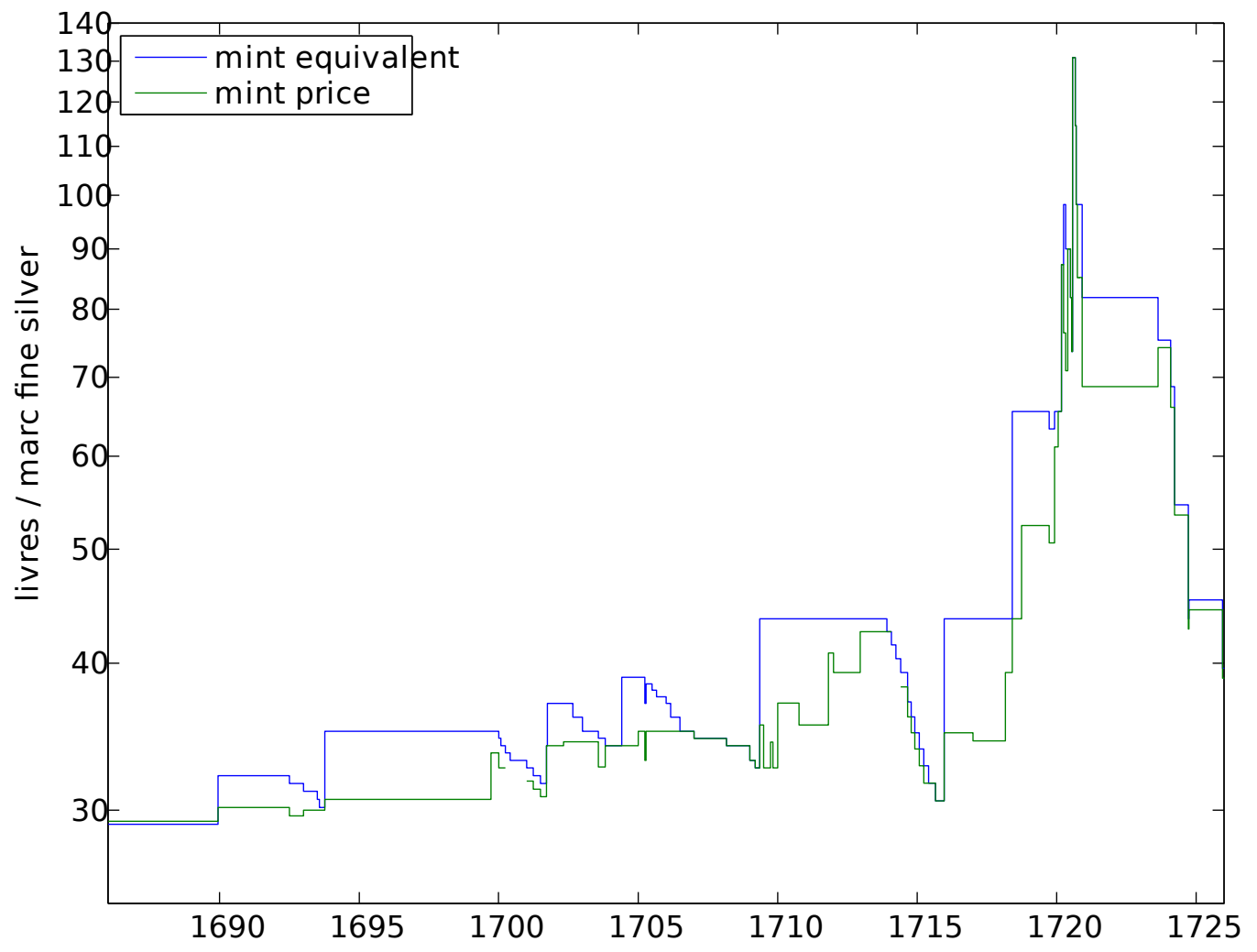

Figure 11. Mint equivalent and mint price of silver coinage, 1688-

1726. The mint equivalent measures the number of livres per constant weight of silver ( 1 marc $=244.75 \mathrm{~g})$. The mint price is the price paid for silver bullion by the mint; the difference between the two lines measures the mint's profit from minting new coins. 
The first instance of reformation took place in 1690. Until then the écu had been worth $3 \mathrm{~L}$. An edict of December 1689 announced that a new coin, of same content but different design, would be henceforth minted and assigned a value of 3.3L. The existing écus were temporarily assigned the value of $3.1 \mathrm{~L}$ and then demonetized. A holder of an old, demonetized écu could not use it as currency, but could sell it to the mint as bullion and obtain new, legally valid écus, or restamped (reformed) old écus in exchange. The price paid by the mint for each old coin was $3.08 \mathrm{~L}$ in new coins. Since the metal content of the écu did not change and the mint made a new écu worth $3.3 \mathrm{~L}$ with the content of each old écu that it bought for $3.08 \mathrm{~L}$, the mint's gross profit was $0.22 \mathrm{~L}$ per écu, or $6.5 \%$. This profit was the purpose of the operation.

From April 1692 the face value of the new coins was progressively reduced from $3.3 \mathrm{~L}$ to return to $3 \mathrm{~L}$, but in October 1693 another reformation took place, issuing a new écu at 3.6 L. From December 1699 this écu was reduced by increments from $3.6 \mathrm{~L}$ to 3.2 L. Other reformations took place in 1701, 1704, 1709, 1715, 1718, 1720 (twice) and 1726. In several instances the new coins were of a different weight but the mechanics and purpose were the same: to force coin holders to sell their coins to the mint at a loss (in terms of metal).

The one exception to the general statement that the media of exchange consisted of gold and silver coin is the period of John Law's Banque générale and later royale. From May 1716 Law's bank issued large denomination notes payable on demand in silver écus (the denominations ranged from 10 to 1,000 écus, later from $10 \mathrm{~L}$ to 10,000 L). By early 1720 the notes had become legal tender and Law intended them to replace specie completely, with only a small 1 L silver coin issued. From May 1720 however his plans went awry and the notes started losing value relative to gold and silver; they were ultimately demonetized in late 1720, and a new coinage (on the standard of 1718) was issued from September 1720. The notes were withdrawn starting in mid1721 and eventually converted into government debt.

\subsection{Prices}

Tickets could be bought for individual seats or for whole boxes. The pricing of single tickets and then boxes are discussed next. 
A useful reminder of the value of prices can be found in Table 3 which shows income per capita for urban social groups in 1788. Even the cheapest seats represented a significant expense for any class below the urban bourgeoisie.

Pricing of tickets at the ComédieFrançaise, as shown for the whole period in Figure 12 can seem bewildering at first, but the figure

\begin{tabular}{lr}
\hline Socialgroup & income/cap(L) \\
\hline Workers & 67 \\
Servants & 90 \\
Shopkeepers and artisans & 150 \\
Bourgeoisie and nobilit & 725 \\
\hline
\end{tabular}

Table 3. Annual income per capita for urban social groups, 1788.

Source: Christian Morrisson and Wayne Snyder, "The Income Inequality of France in Historical Perspective," European Review of Economic History 4, 2000, 59-83. shows certain patterns, and its history can be understood on the basis of two principles: (a) a stable set of four price categories (six from 1782), and (b) the coexistence at all times of two price schedules which alternate depending on the day. Each price schedule comprises four prices, for each seating category. I will refer to these schedules as "regular" and "premium." 


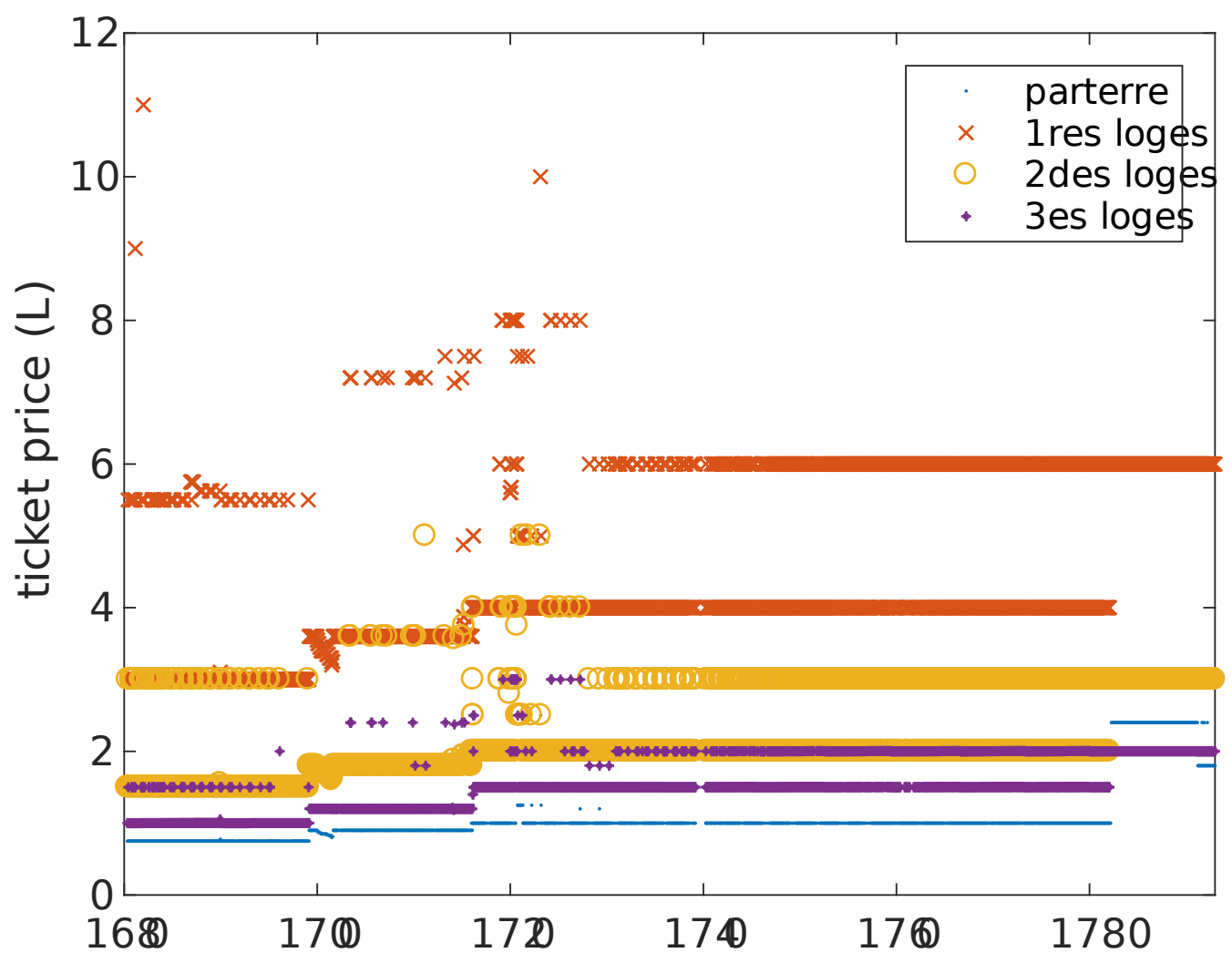

Figure 12. Seat prices by categories.

Several factors were also at play over time, complicating the picture without obscuring the pattern: (a) stage seats were occasionally priced differently, until 1730; (b) two taxes were levied in 1699 and in 1716 which increased prices; (c) the monetary manipulations described above occasionally affected prices charged; and (d) the alternation between the two schedules varied over time. Specifically, the lower of the two schedules was by far the most common one until 1753, so that one can think of a base or regular schedule and a premium schedule. After 1753 the lower schedule became much less common, so that it is better to think of a discount and a regular schedule. After 1782 a single schedule prevailed at all times.

\section{Seating Categories}

The price categories were limited to four (with an occasional fifth) until 1782, then increased to six. $\underline{42}$ The cheapest category comprised the pit (standing room only), the next cheapest comprised the third (and, after the 1770, the fourth) boxes. The next category were the second boxes. Finally, the most expensive seats comprised the first level of boxes (and the ground-level boxes after 1770), the parquet, the amphithéâtre, and the stage seats. $\underline{43}$ 
The occasional fifth category arises between 1694 and 1730 because stage seats are charged a different (always higher) price. This happened a few times in the 1690s (the premiere of Sancho Pansa in 1694 that of La Foire Saint-Germain and of Polixène in 1696) and for another of Psyché in 1704. It also happened at season closings, first in 1705 , then again in 1706, 1708, and 1709. It was used most regularly between December 1698 and March 1699, and between October 1713 and February 1715; then rarely until 1730. $\underline{44}$ Stage seats were removed in 1759.

\section{Pricing and currency variations}

It is convenient to proceed chronologically and distinguish several periods: from 1680 to the first tax increase in 1699, then from 1699 to the second tax increase in 1716, then from 1716 to the new theater in 1782. For each period I will discuss both regular and premium prices. Appendix 2 provides details on the pricing schedules used in these three periods.

Until 1687 the regular schedule of prices was 0.75/1/1.5/3 L. This structure corresponded neatly to the coins that had been in circulation since 1640. $\underline{45}$ The silver coins, the écu and its fractions, were valued at $3 \mathrm{~L}, 1.5 \mathrm{~L}, 0.75 \mathrm{~L}$ and $0.25 \mathrm{~L}$, while the gold coins, the louis and its double and half, were valued at $11 \mathrm{~L}, 22 \mathrm{~L}$, and $5.5 \mathrm{~L}$. The price structure at the Comédie-Française expressed itself simply in terms of coins: a parterre ticket was a quarter-écu, a 3rd box was a quarter and a twelfth, a 2nd box was a half-écu and a 1st box was an écu.

During the same period premium prices were usually 1.5/1.5/3/5.5 L, namely a halfécu, an écu and a half-louis, with a few variations (notably, the premium parterre price was sometimes doubled, sometimes not between November 1681 and February 1682).This corresponds to a doubling of regular prices, except for the premium lower boxes set in terms of a gold coin. $\underline{46}$ Indeed the registers sometimes note that "prices were doubled" (on a pris le double).

The first monetary mutation to occur since 1641 took place in 1686-87, when the value of the louis varied: from August 15, 1686 it was $11.5 \mathrm{~L}$, then from October 27 it was 11.25 L, then from December 10 it was $11.6 \mathrm{~L}$ (see Appendix 1 for details of coin valuations over time). The premium price of the lower box seat varied accordingly, so that it remained constant in terms of gold coin. $\frac{47}{}$ Also, for a brief period in December 1689 the lower tier of ticket prices followed the silver écu which had gone from $3 \mathrm{~L}$ to 3.1 L while a new écu of 3.3 L was issued, and for one day (December 21) they are noted in the register as "écu”, “demi écu”, "quart d'écu." But, after December 1689, 
the louis continued to vary, and was in fact replaced twice by new louis of different values but the Comédie-Française's premium prices returned to multiples of 11 and seemed to ignore the subsequent variations entirely. Nor were the contemporaneous variations in the value of silver coins taken into account.

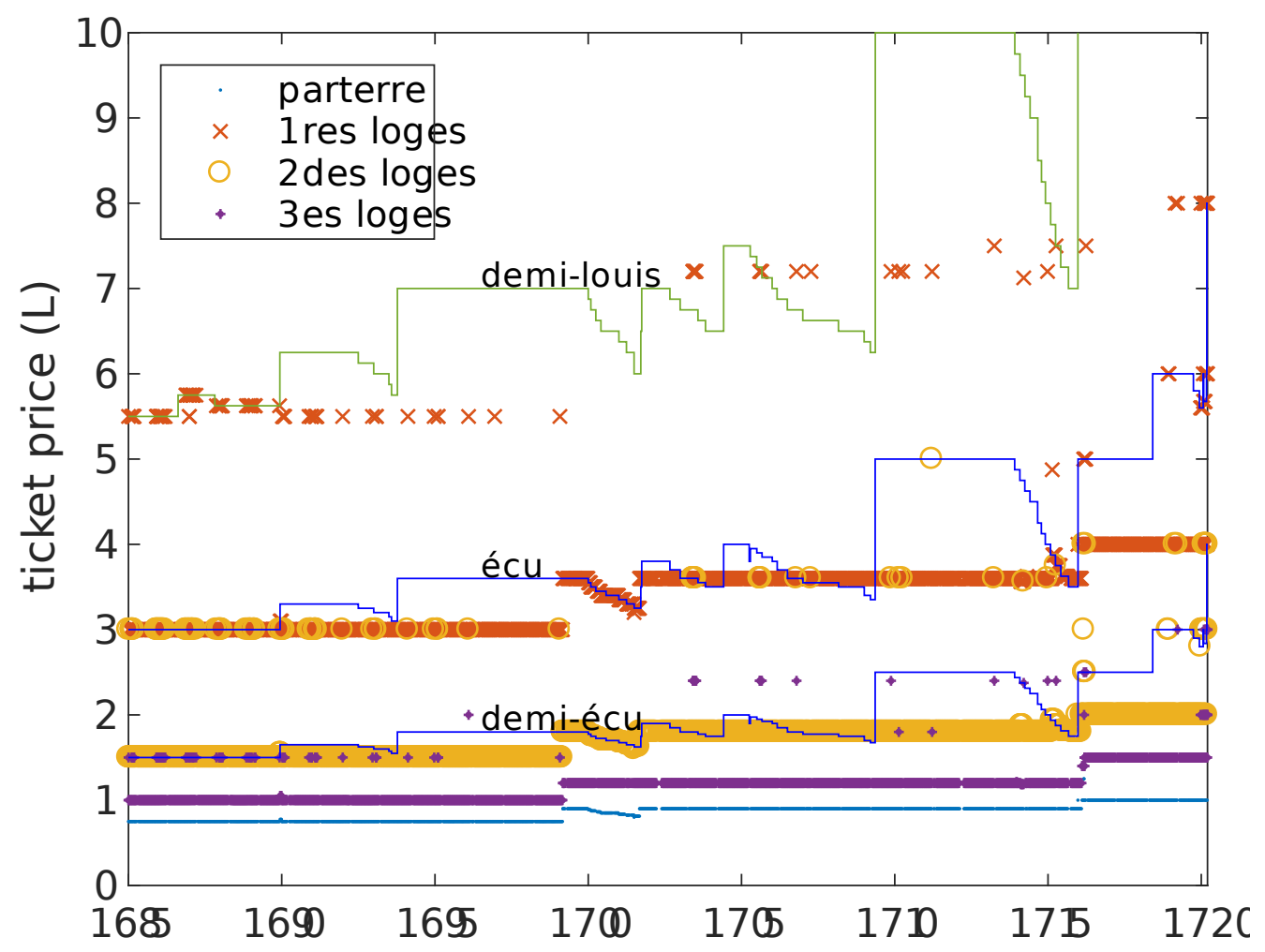

Figure 13. Prices of selected categories of seats, along with the nominal value of the gold demi-louis and the silver écu and demiécu.

The second period begins with the imposition of a poor tax. $\underline{48}$ On March 5, 1699 prices at the Comédie-Française increased by $20 \%$, to $0.9 / 1.2 / 1.8 / 3.6 \mathrm{~L}$ for the regular schedule, and an exact double of 1.8/2.4/3.6/7.2 L for the premium schedule. This aligned both schedules on the current face values of silver coins: since the reform of October 1693 the écu was $3.6 \mathrm{~L}$, hence all prices (except those of the $3 \mathrm{~d}$ boxes) could be expressed with this coin and its half $(1.8 \mathrm{~L})$ and quarter $(0.9 \mathrm{~L})$. From 1699 to the imposition of an additional tax in 1716 monetary variations were numerous, but rarely affected the Comédie-Française's prices, except in two instances.

The first instance came just a few months after the imposition of the tax. A series of arrêts du conseil, starting on 22 December 1699, reduced the value of the écu from 3.6 L to $3.2 \mathrm{~L}$. Accordingly we see the prices of three categories falling exactly in step 
with the écu in January, February, April, June 1700, January, April, and July 1701, keeping prices in terms of the silver coinage. The prices of the 3rd boxes, however, were left unchanged. In September 1701 a new reformation of coinage resulted in a new issue of écus with face value of 3.5 L. The Comédie-Française, however, returned its regular schedule of prices back to the level of 1699, ignoring this and subsequent variations in coins for 14 years, presumably because the Comédie-Française's prices did not match any specific denomination. $\underline{49}$ Premium prices, which were very rarely used during that period, were a simple doubling at 1.8/2.4/3.6/7.2 L; with a few exceptions they also ignored monetary variations. $\underline{50}$

Prices at the Comédie-Française were once again affected by monetary variations during a progressive devaluation of the écu from $5 \mathrm{~L}$ to $3.5 \mathrm{~L}$ from December 1713 to September 1715. At the end of that process, from February to September 1715 the two most expensive seats exactly tracked the value of the écu and half-écu. The two cheapest seats remain unchanged throughout.

Premium prices, rarely imposed, varied less. The only variations are that two cheapest seats were either unchanged, increased by half, or doubled; the 2nd boxes were charged an écu of $5 \mathrm{~L}$ at the 1711 closing, while the 1st boxes were charged an écu and a half $(7.5 \mathrm{~L})$ at the 1713 closing, and the prices of the 1714 and 1715 closings were set at convenient fractions of the then current price of the écu $(4.75 \mathrm{~L}$ and $3.75 \mathrm{~L}$ respectively).

The third period began when the additional poor tax in favor of the Hôtel-Dieu took effect on February 10, 1716, and prices increased by $11 \%$ to $1 / 1.4 / 2 / 4$ L. For a while, during the month of March 1716, the Comédie-Française seemed to experiment with different price schedules. During the 1716-1718 seasons, however, the price schedule was $1 / 1.5 / 2 / 4 \mathrm{~L}$ with only one use of a premium schedule for the 1719 closing. This schedule remained in place until the move to the new theater in 1782 , with the exception of the last period of monetary instability to impact prices at the ComédieFrançaise, during and right after John Law's System, in 1720-21.

In January 1720 the regular schedule was used two thirds of the time but the premium schedule changing repeatedly. From February to mid-March three price schedules alternated: the regular, an intermediate, and a doubled. From mid-March to August 9 the regular (on the petits jours) and the doubled schedules alternated from August 10 to September 30 the regular schedule was raised 50\% for the lowest and highest 
categories. Finally, from October 1720 to April 1721 the regular schedule was scaled back while the premium schedule became rare.

With the 1721 season the regular schedule returned to 1/1.5/2/4 L and did not deviate for the next sixty years, but with a change in frequency as we shall see. The premium price structure took a little longer to settle, and varied somewhat from 1721 to 1732 . From the 1730 season the use of the premium schedule increased and, after some hesitation on whether to charge more on third boxes during the 1731 and 1732 seasons, the schedule itself settled permanently at 1/2/3/6 L.

\section{The use of premium pricing}

Figure 14 shows how frequent premium pricing was between 1680 and 1782, when the distinction between schedules disappeared. In the early years premium pricing was used either for first runs of new plays or for significant revivals (Corneille's Andromède in 1682, his Toison d'or in 1683, Molière's Psyché in 1684). Not all premieres received premium pricing: only 40\% between 1680 and 1695.

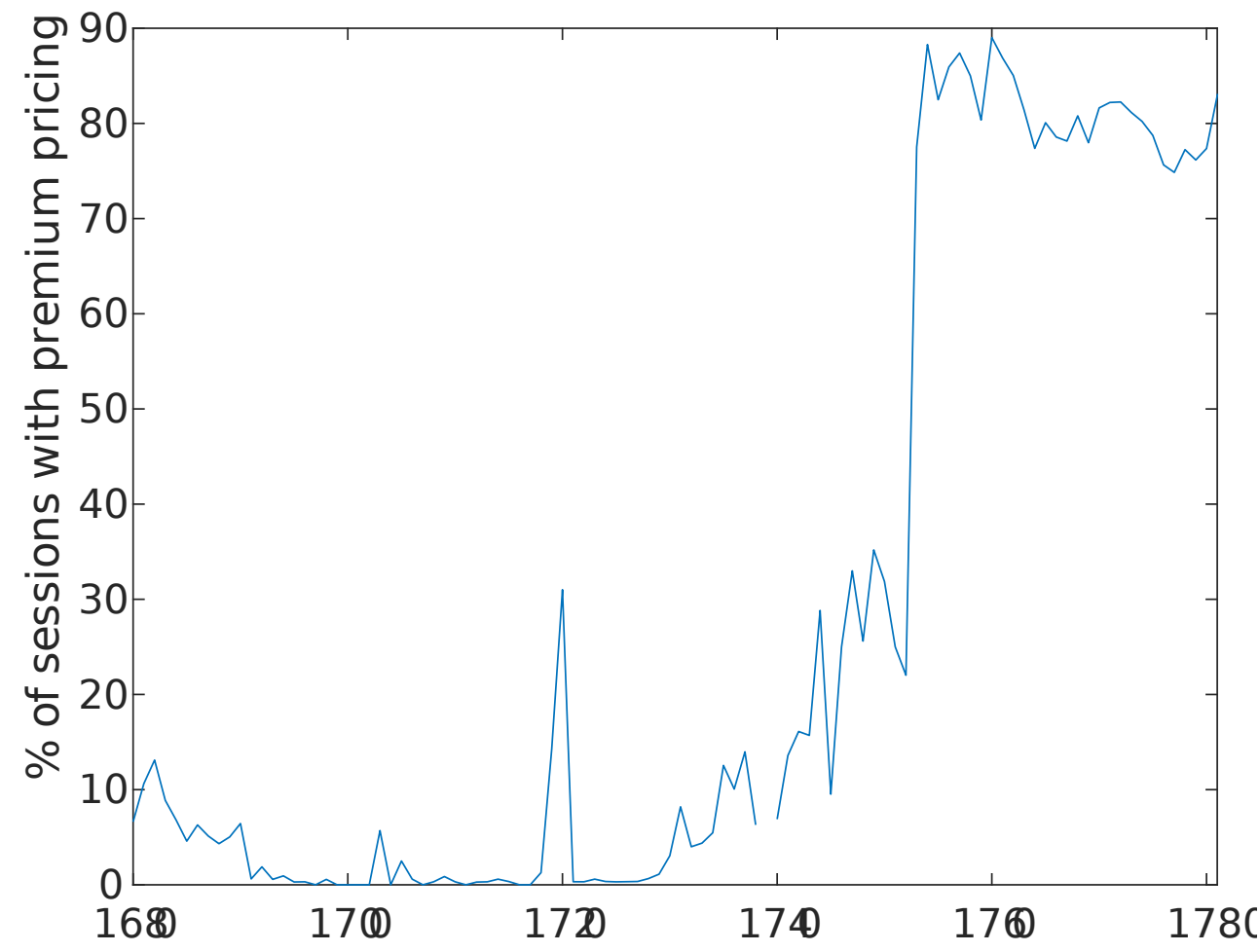

Figure 14. Frequency of premium pricing, by season.

Occasions for premium pricing became rare and more eclectic after 1695: a few premieres (Genest's Polymneste in 1699, La Grange's Méléagre in 1699, Destouches' 
Curieux impertinent in 1709, Longepierre's Électre in 1719), a few revivals (Molière's Psyché in 1703, Corneille's Circé in 1705), the return of a famous actor (the elder Baron in 1710), visits by illustrious figures (the heir apparent or Dauphin in 1696, the Old Pretender in 1706, the Elector of Bavaria in 1709), and emerging traditions (on the last day of the season or closing in 1707 and from 1710, except in 1717-18; the Christmas performance of Corneille's Polyeucte in 1714, 1716, and 1719).

As we saw above, a form of premium pricing returned in 1720 , but mainly as a way to keep up with inflation. Once prices returned to normal premium pricing was again

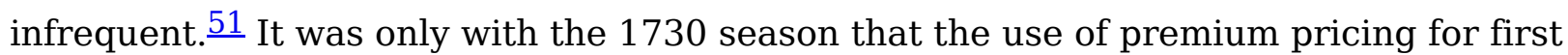
runs (and not just premieres) returned. $\underline{52}$ From 1730 to $175355 \%$ of new plays received premium pricing during their first run. Moreover season openings (from 1742) and revivals started receiving premium pricing as well: Molière's Bourgeois gentilhomme in 1736, the Triomphe du temps and Alzire in the 1740 season, etc. Voltaire's Mérope was the first play to receive premium pricing beyond its first season.

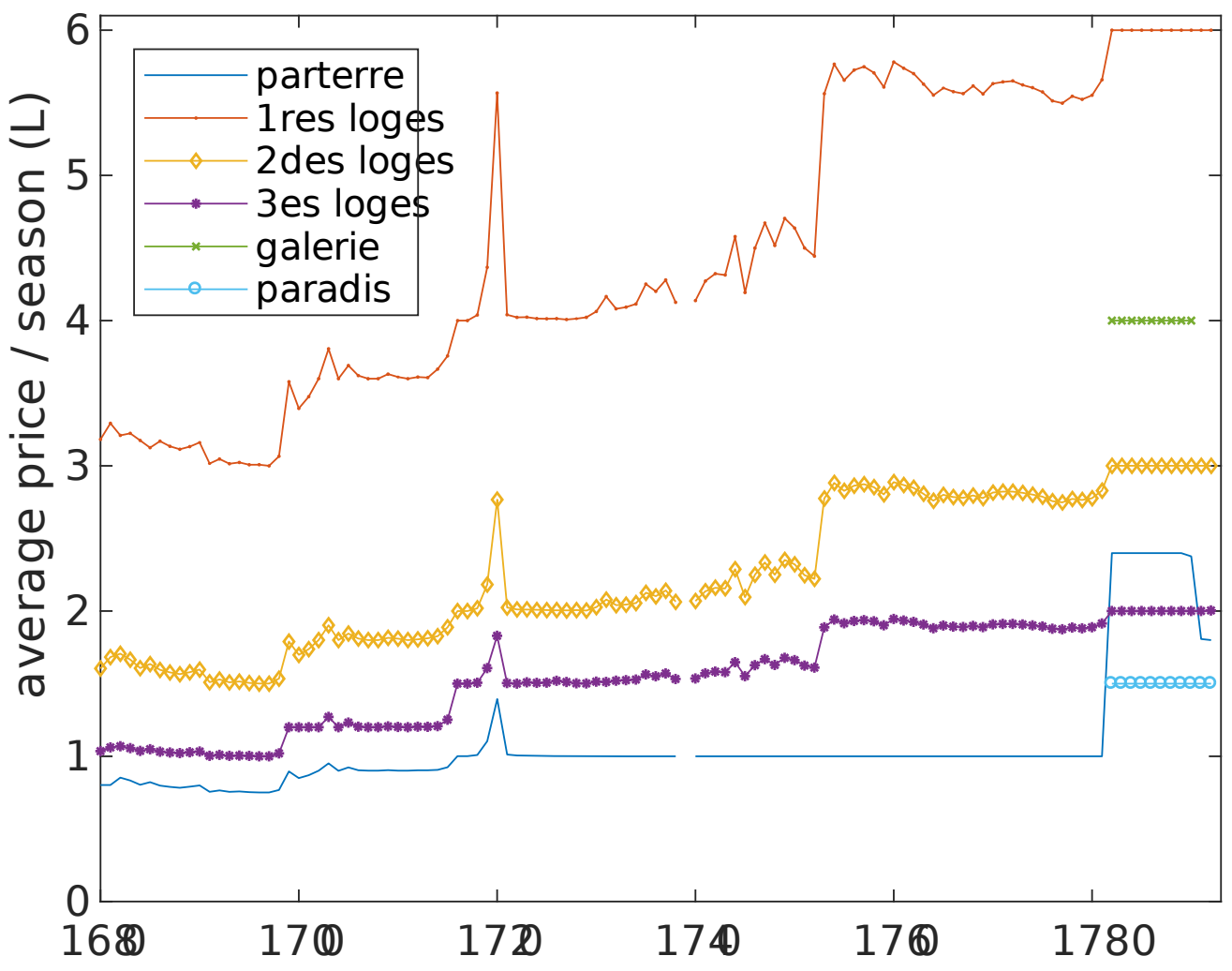

Figure 15. Average prices of selected categories of seats, by season. 
As Figure 14 shows, premium pricing was steadily becoming more frequent, but a big change took place with the 1753-54 season. The pricing structure remained the same, alternating between $1 / 1.5 / 2 / 4$ and $1 / 2 / 3 / 6$, but the higher prices were charged much more frequently. As a result the average price charged for each price category increased. [Fig. 15] Compared to the 1740-52 averages, prices effectively increased by $26 \%$ for the top two categories and by $18 \%$ for the third (the parterre prices were not affected). For the seasons 1753-1782, the lower price structure prevailed $19 \%$ of the time only, almost exclusively on the petits jours of Tuesday and Friday, while before 1752 the higher prices prevailed only $15 \%$ of the time, and usually on Mondays, Wednesdays, and Saturdays. [Fig. 16] Also noteworthy is that every single premiere after 1753 took place at premium pricing; presumably the entire first runs were scheduled on premium nights as well.

In sum, two things happened in 1753: prices went up by a quarter, and discount nights became perfectly predictable. Programming was scheduled around pricing rather than pricing dictated by performances. In macroeconomic parlance, pricing changed from state-dependent to date-dependent.

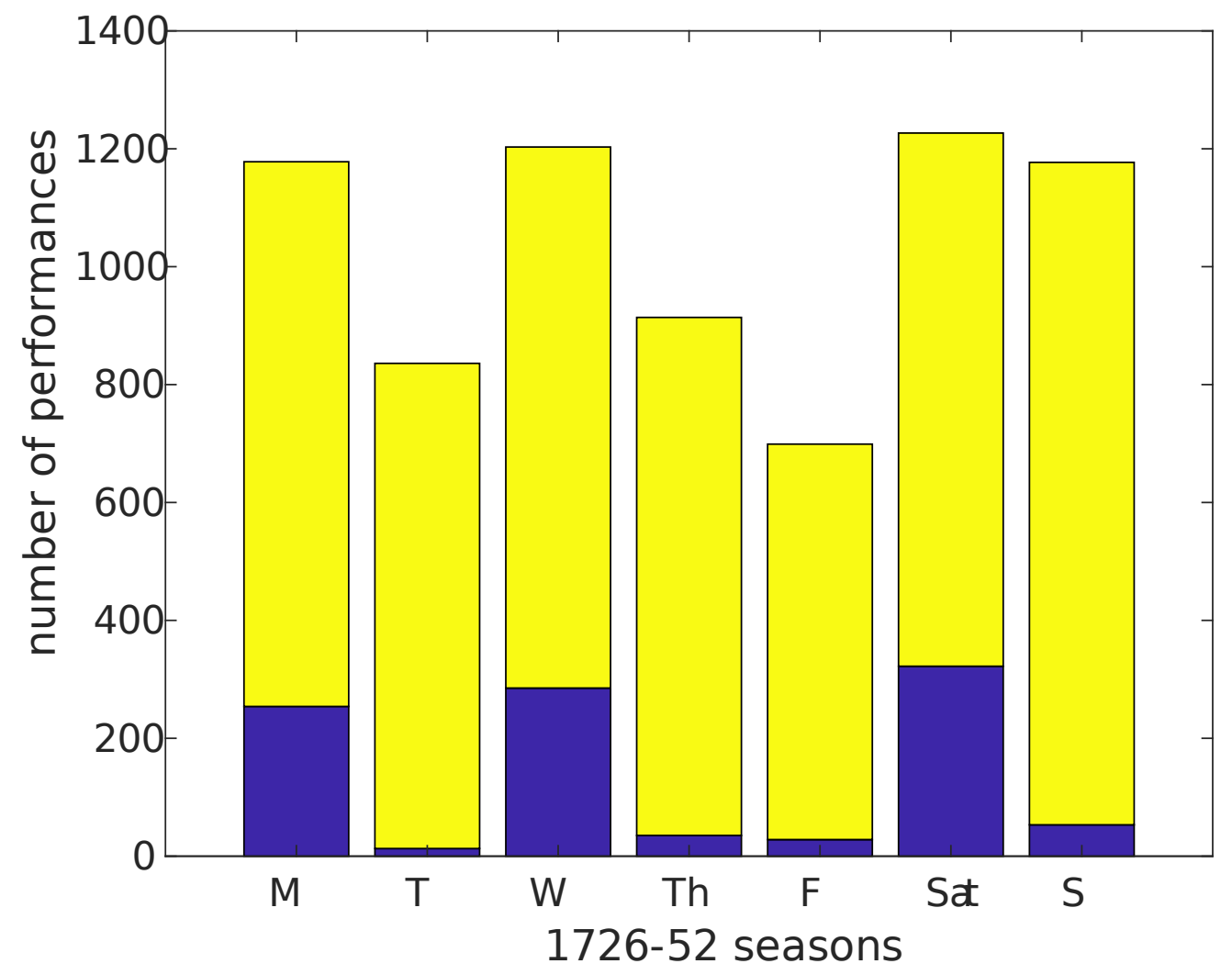




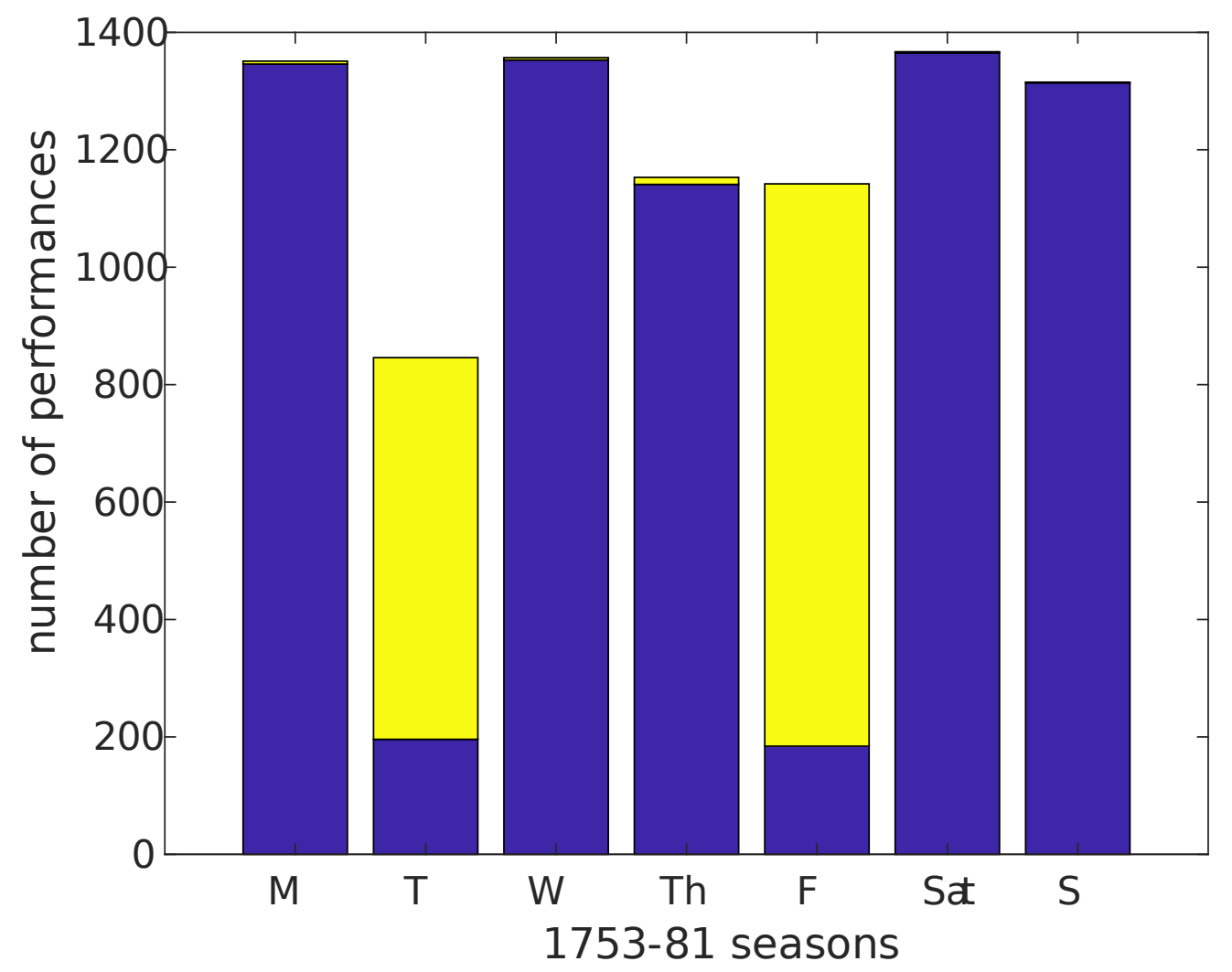

Figure 16. Number of performances at full (dark blue) and discount (red) prices, by day of week, during the 1726-52 (top panel) and 1753-81 (bottom panel) seasons.

\section{The last venue}

When the Comédie-Française moved to its new theater for the 1782-83 season the pit, renamed parquet had benches and ceased to be the cheapest category; also, two categories were added, the galerie and the amphithéâtre des 3es loges or paradis, on the top floor. The practice of discount pricing for off-days disappeared, and the only change thereafter was a lowering of the parterre on March 27, 1791 from $2.4 \mathrm{~L}$ to $1.8 \mathrm{~L}$. Thus the theater seemed able to dispense with a tool it had used fairly frequently.

\section{Pricing of the loges}

Having untangled single ticket pricing, we can now understand box pricing. The difficulty here is that, until 1782, we do not know exactly the capacity of the boxes. As it turns out, box prices followed the alternation of regular and premium pricing that we have identified for single tickets, and appear to have been proportional to seating 
capacity. Hence, in the vast majority of cases one can make a plausible guess for the capacity of the box based on its rental price.

The registers provide some limited information on the types of boxes. $\underline{53}$ At first they were called loges but sometimes differentiated into premières and secondes, referring to the first or second level. From 1687 to 1754 the terminology is loge basse and loge haute, or lower and upper boxes.

As with single tickets, box rentals initially matched the existing coinage. In 1680 upper boxes rented for $12 \mathrm{~L}$ ( $24 \mathrm{~L}$ on premium nights), namely four (eight) silver écus; lower boxes rented for $33 \mathrm{~L}$ (44 L on premium nights), namely three (four) gold louis.

Compared to single ticket prices, box prices corresponded to a capacity of eight seats.

After the value of the gold louis was altered in 1687 to $11.5 \mathrm{~L}$, the "gold" prices of lower boxes moved accordingly to $34.5 \mathrm{~L}$ and $46 \mathrm{~L}$ while the "silver" prices of upper boxes remained unchanged. In October 1687 the louis was lowered to $11.25 \mathrm{~L}$, and on December 12,1689 to $11.6 \mathrm{~L}$, and the gold prices of lower boxes followed. $\underline{54}$ But from January 1690 the prices of boxes returned to the earlier structure of 12/33 for regular prices and 24/44 for premium prices. In September 1695 regular prices became 12/24, exactly 8 times the single ticket prices. As we saw earlier premium pricing became rare, but when it was used box prices increased in strict proportion.

When the first poor tax was imposed in 1699 box prices increased by $25 \%$ instead of $20 \%$, from $12 / 24$ to $15 / 30$ for a ratio of $81 / 3$ to single tickets. When the second poor tax was imposed in 1716 box prices increased to 16/32 and restored the ratio of 8:1 to single ticket prices which was maintained until 1723, in line with the box capacity. $\underline{55}$ During the 1722 season there are no box rentals. Presumably some remodeling of the theater was done that year, because afterwards two distinct prices were charged for upper boxes, either eight and ten times the single ticket price (regular or premium). It seems reasonable to infer that new boxes with ten seats had been created, as confirmed by an examination of a mid-18th century blueprint of the venue. $\underline{56}$

From the 1754 season the boxes are named premières and secondes and new categories appear: half-boxes (first or second) in 1758, balcons in 1759, troisièmes loges and petites loges (first built around 1753 on the third level and presumed to have held four seats) in 1765. 
Databases, Revenues, \& Repertory: The French Stage Online, 1680-1793 • Databases, An Analysis of Revenues at the Comédie-Française, 1680-1793

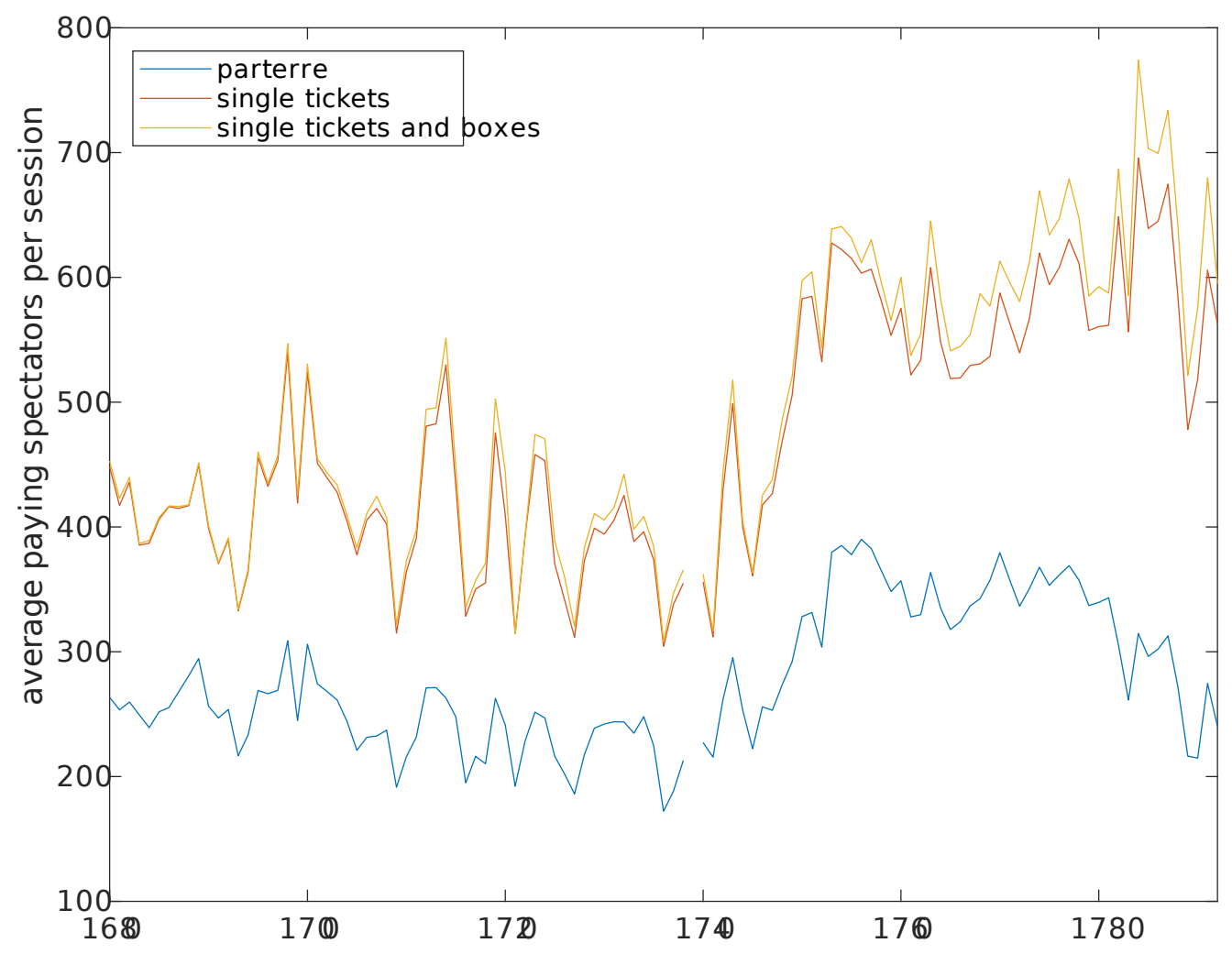

Figure 17. Number of paying spectators per session: parterre, all single tickets, all single tickets and all rented boxes (average per season).

When the Comédie-Française moved to the Tuileries the balcons disappear and the price categories multiplied. In the new theater in 1782 box capacities were specified in the registers. Reconstructing the rates of boxes becomes more difficult between 1758 and 1782, but can be done as long as one distinguishes between regular and discount prices. This is what I do in Table 4, distinguishing between discount (A) and regular (B) prices. Box capacities are known for 1782-93, I estimate it for the earlier periods. 


\begin{tabular}{|c|c|c|c|c|c|c|c|c|}
\hline \multirow[b]{3}{*}{ categoy } & \multirow[b]{3}{*}{ capacity } & \multicolumn{6}{|c|}{ box prices(L) } & \multirow{3}{*}{$1782-93$} \\
\hline & & \multicolumn{3}{|c|}{ to 1758} & \multirow{2}{*}{$\frac{1758-70}{B}$} & \multicolumn{2}{|c|}{$1770-82$} & \\
\hline & & $A$ & $B$ & A & & $A$ & $B$ & \\
\hline premièrs & 2 & & & & & & 12 & \\
\hline \multirow[t]{8}{*}{ loges } & 3 & & & & & & & 18 \\
\hline & 4 & & & & 24 & 16 & 24 & 24 \\
\hline & 5 & & & & 32 & & 30 & 30 \\
\hline & 6 & & & & 36 & 24 & 36 & 36 \\
\hline & 7 & & & & & & & 42 \\
\hline & 8 & 32 & 48 & 32 & 48 & 32 & 48 & 48 \\
\hline & 10 & & & & & & & 60 \\
\hline & 12 & & & 48 & & 48 & 72 & \\
\hline secondes & 2 & & & & & & & 7.5 \\
\hline \multirow[t]{9}{*}{ loges } & 3 & & & & & & 10 & 11.25 \\
\hline & 4 & & & & & 10 & 15 & 15 \\
\hline & 5 & & & & & 12.5 & 18.75 & \\
\hline & 6 & & & & & 15 & 22.5 & \\
\hline & 6 & & & 16 & 24 & 16 & 24 & 22.5 \\
\hline & 8 & 16 & 24 & 20 & 30 & 20 & 30 & \\
\hline & 10 & 20 & 30 & & 36 & & & \\
\hline & 24 & & & & & & 90 & \\
\hline & 28 & & & & & & 105 & \\
\hline troisièmes & 2 & & & & & & 5 & 5 \\
\hline petite & 3 & & & & & & 7.5 & 7.5 \\
\hline \multirow[t]{9}{*}{ loges } & 4 & & & 7.5 & 10 & 7.5 & 10 & 10 \\
\hline & 5 & & & 10 & 11.25 & 10 & & 12.5 \\
\hline & & & & & 12.5 & & & \\
\hline & 6 & & & & 15 & & 15 & 15 \\
\hline & 7 & & & & 18 & & & 17.5 \\
\hline & 8 & & & 15 & 20 & & 17.5 & 20 \\
\hline & 8 & & & & & & 20 & 20 \\
\hline & 10 & & & 16 & 24 & & & \\
\hline & 12 & & & 22.5 & 37.5 & & & \\
\hline \multirow[t]{2}{*}{ balcons } & & & & 10 & 15 & & & \\
\hline & & & & 15 & 22.5 & & & \\
\hline
\end{tabular}

What emerges is that, in the 1750s, the pricing of ${ }_{30}^{24}$ irst boxes remained unchanged, but the pricing of second boxes increased relatije to sjingle ticket prices, which were $2 \mathrm{~L}$ 
and $3 \mathrm{~L}$ on regular and premium nights: boxes were rented as multiples of $2.5 \mathrm{~L}$ and 3.75 L respectively. Likewise, when third boxes were rented whole their prices, at multiples of $2 \mathrm{~L}$ and $2.5 \mathrm{~L}$, were higher than single tickets at $1.5 \mathrm{~L}$ and $2 \mathrm{~L}$. This pricing was retained in the new venue of 1782, while an even greater variety of box sizes was introduced.

\subsection{Quantities}

If prices cannot fully account for the increase in revenues, we must turn to quantities, that is, tickets sold. Having untangled the pricing schedules allows me to construct daily attendance figures. These cannot include free seats, which could be numerous: actors, authors, government officials were entitled to varying number of free seats which cannot be tallied.

\subsection{Attendance}

Figure 17 shows all seasonal averages for attendance over the period. The pit comprised between 50 and $60 \%$ of audiences, although it declined markedly in the last years. Daily box rentals turn out to be quantitatively minor, as pointed out earlier.

Behind the seasonal averages lies an amazing degree of variance. Figure 18 shows the daily numbers over the whole period; each dot in the graph corresponds to a session. The changes in venues are marked by the vertical lines and the season average by the thick line. The pre-1782 maximum was 1592, reached on December 11, 1730, while the minimum was 12, reached on June 23, 1712 and February 12, 1712. The Tuileries venue between 1770 and 1782 was obviously marked by capacity constraints, and the move to the new theater in 1782 allowed for much larger audiences. 


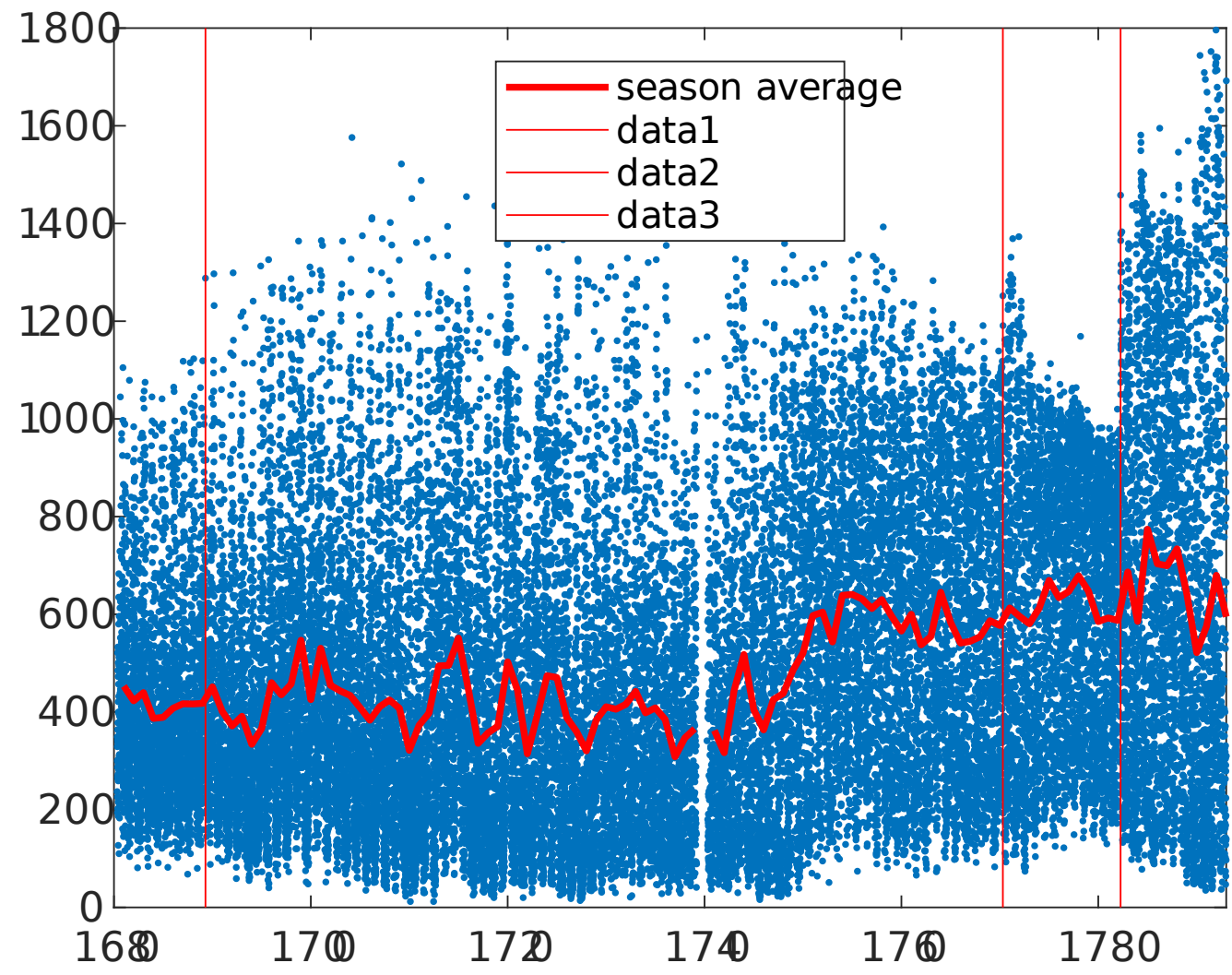

Figure 18. Number of paying spectators per session.

Figure 19 breaks down daily attendance by seating category. The capacity constraint is evident in the panel for the parterre, where a maximum of 450 seats was often binding between 1773 and 1782. This number does not correspond to the capacity reported in the archival document mentioned above, which gives a figure of 600 . It seems related to attempts by the police to limit the parterre audience. $\underline{57}$ The move to the new venue allowed for a great expansion of seating, particularly at the end, in the 2nd and 3rd level of boxes. 

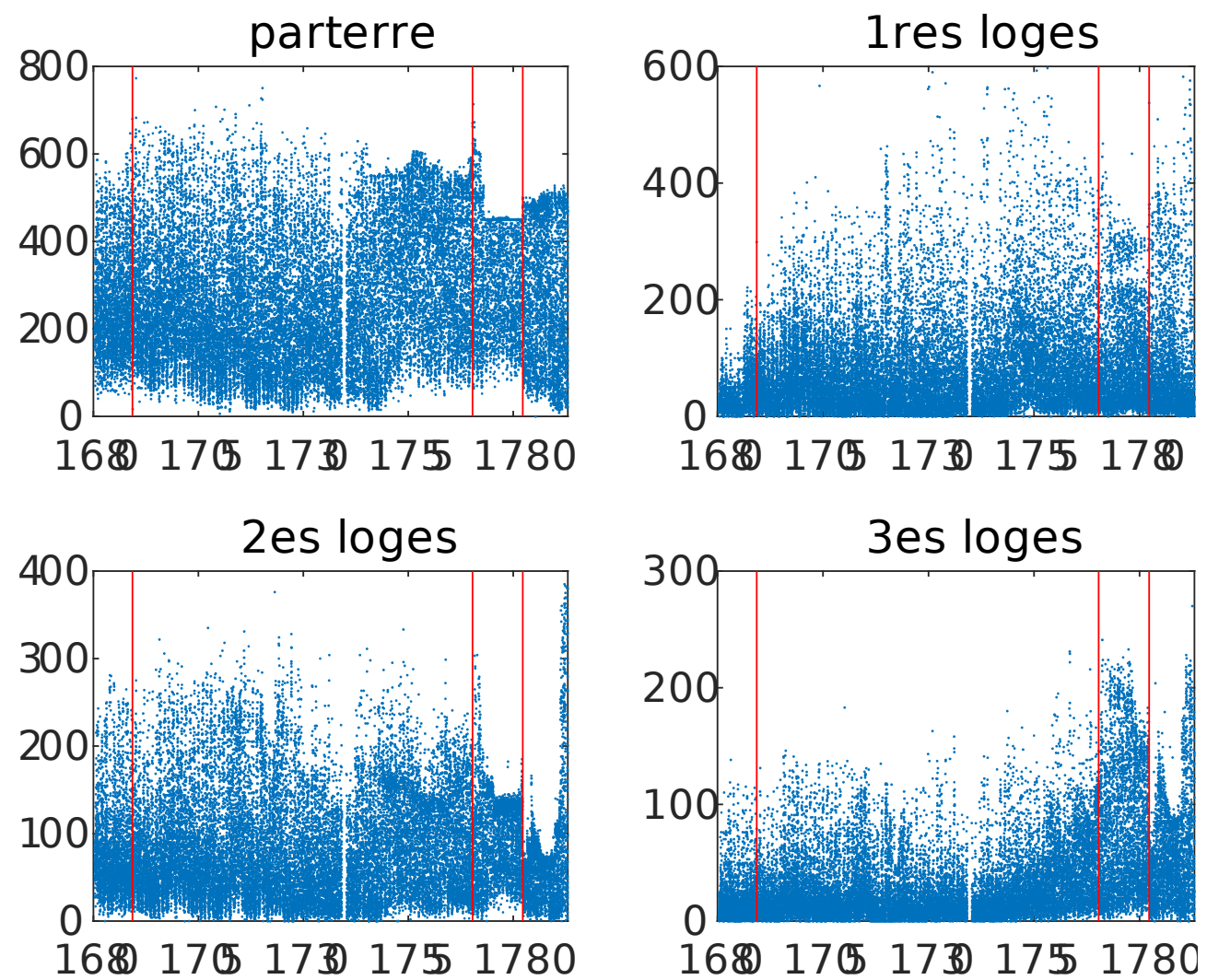

Figure 19. Number of paying spectators per session, by price category.

Figure 20 shows the histograms of attendances by sub-periods. The numbers on the horizontal axes represent deviations from a detrended and seasonally adjusted mean: that is, they remove changes in overall attendance over time, over the course of the season and the course of the week. A shift in the distribution toward the right (more attendance) is evident after 1749, and becomes more pronounced at the Tuileries (1770-82), where "piling up" occurs at the right of the distribution because of capacity constraints. The shape of the distribution in the last period is more similar to the first period, but with a greater spread, indicating more successful nights. 

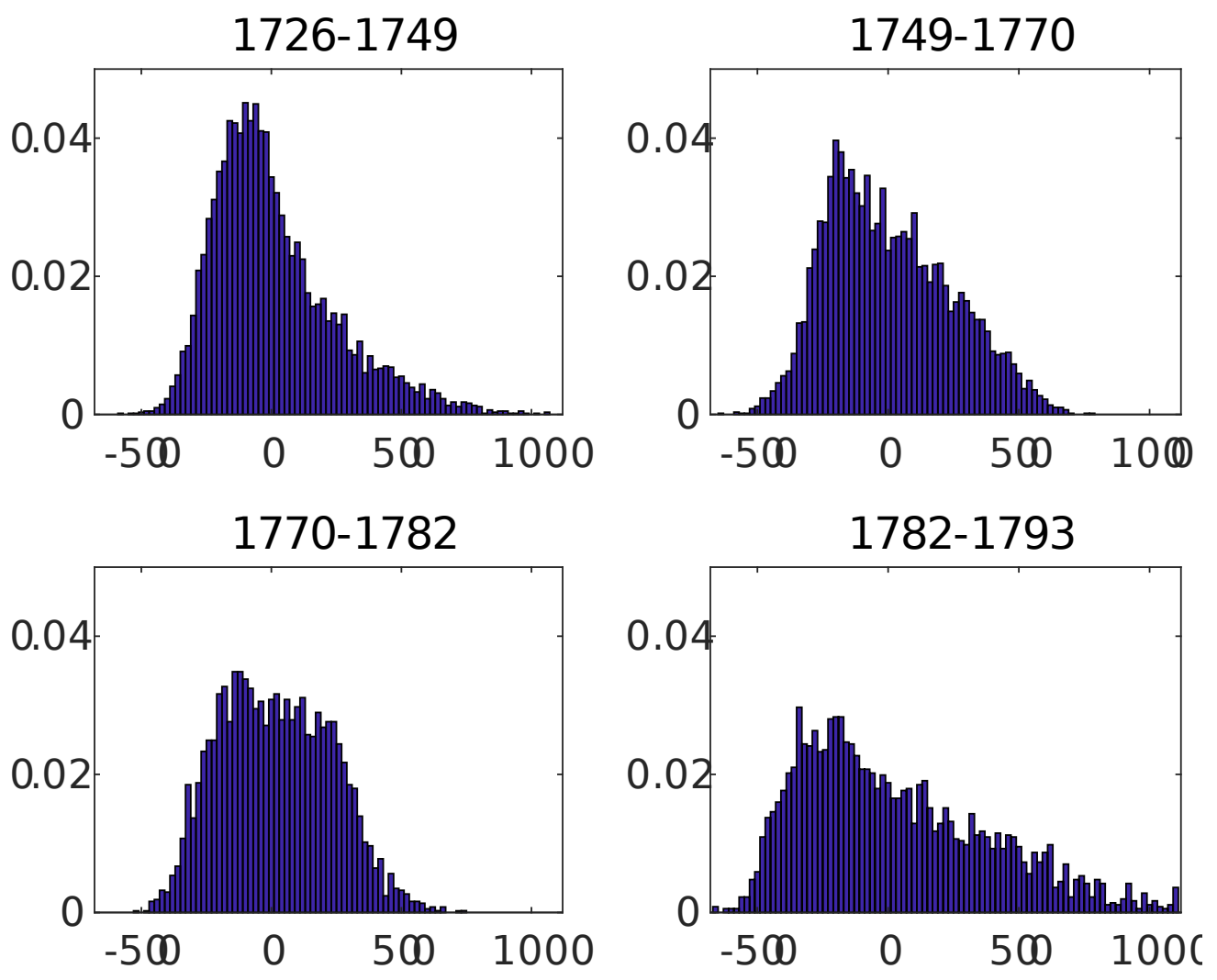

Figure 20. Distribution of attendance numbers per session, relative to mean and seasonally adjusted.

These distributions, of course, do not represent the uncertainty faced by the ComédieFrançaise, because it results from the programming choices made by the actors every week.

\section{Programming Strategies}

Even if we accept the existence of a rising demand for theater in Paris after 1748, can we understand what the Comédie-Française did to take advantage of it? In other words, can revenues be explained by programming strategies?

A first pass at this question consists in examining some statistics that will shed light on programming choices. The maintained assumption is that these choices were made by the actors who were in effect the shareholders of the Comédie-Française, bearing the day-to-day risk, while catastrophic risk was possibly insured by the king. $\underline{58}$ 
Programming was indeed decided by the actors at their weekly Monday meeting, and programs were set for periods of two weeks. $\underline{59}$

\subsection{Diversity}

Mlle Clairon stated in her memoirs: “Ce n'est qu'en variant les spectacles qu'on peut espérer de faire de bonnes recettes." Contrary to the Opéra, where only a handful of works were performed in each season and were performed night after night, the Comédie-Française, by tradition, regulation, and self-interest, had to vary its offerings. $\underline{60}$

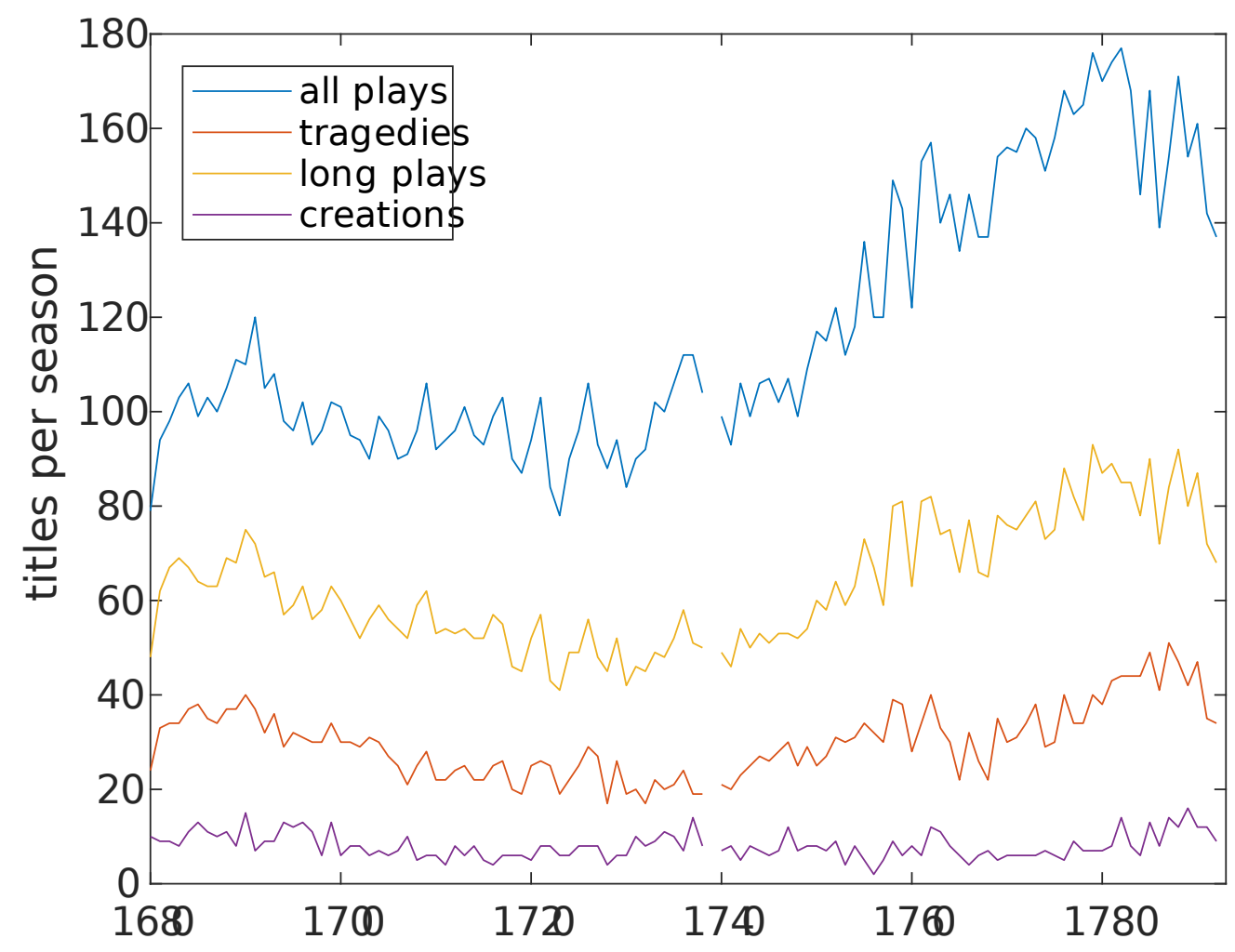

Figure 21. Number of distinct titles per season, 1680-1792.

Figure 21 shows several measures of diversity by season. All are counted in number of distinct titles: all plays, tragedies, long plays (4 or 5 acts), and new plays or creations. Two periods again emerge: before 1750, the total number of plays is stable at around a hundred. The number of tragedies and long plays both decline markedly, while the rate of creations is relatively constant, and low: the typical seasonal repertory consists of one new play in ten. After 1750, the total number of plays rises to reach almost 180; 
both downward trends in long plays and tragedies are reversed, while the rate of creation changes little.

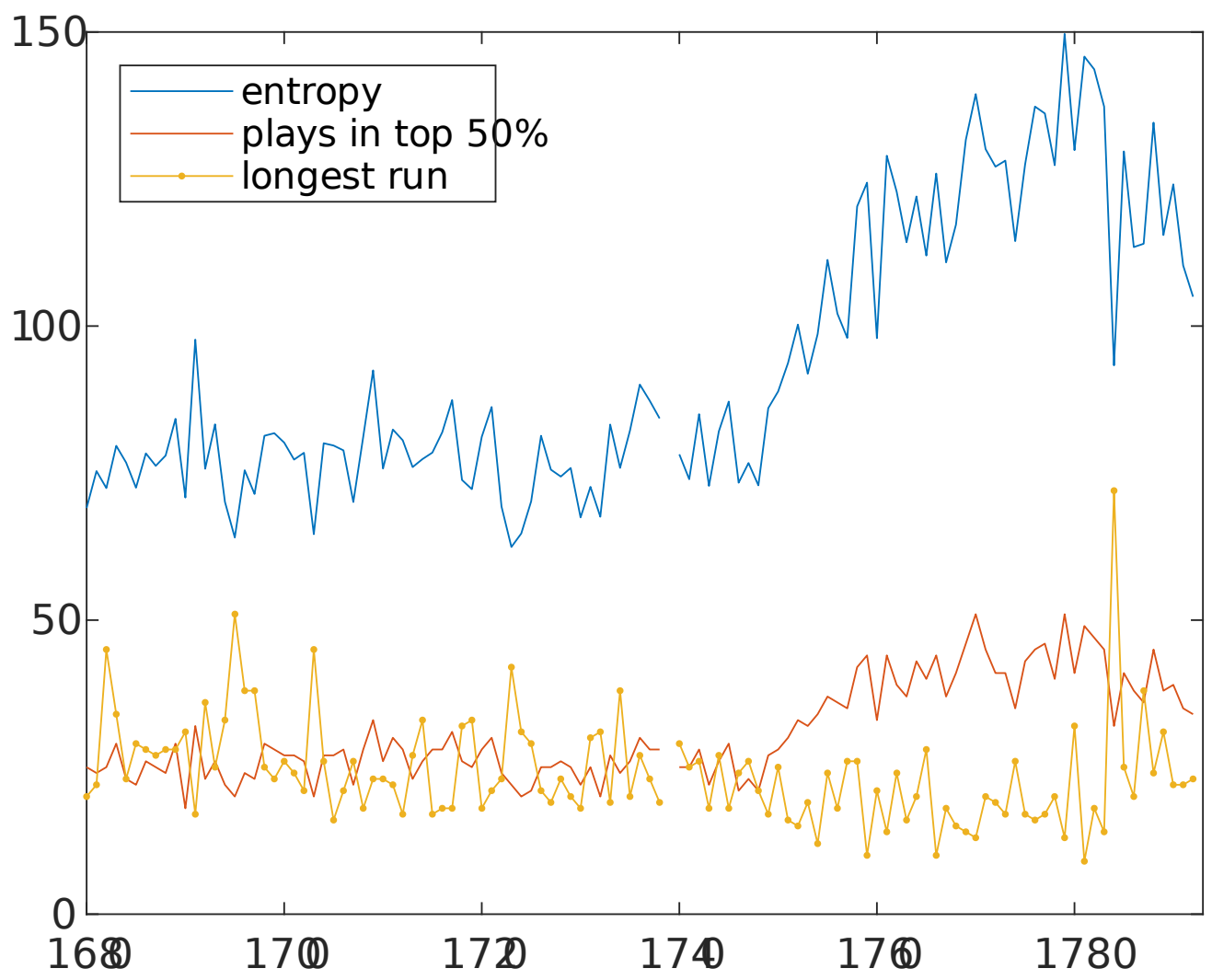

Figure 22. Number of titles, measure of diversity, number of plays representing the top 50\% performances, length of longest run per season, 1680-1792.

These measures count numbers of titles, but do not adjust for variety. Figure 22 tries to do so. One possible measure takes into account the fact that 99 performances of play A and one performance of play B offers less variety than 50 performances of each. The measure is called relative entropy, a concept borrowed from information theory and used, for example, to measure diversity of an ecological environment. Intuitively, it quantifies the uncertainty about which species one might encounter in a given environment.

Suppose that $N$ plays are performed in a given season, and the share of each play $i$ in the total performances is $p_{i}$. Then the entropy associated with this season is $-\Sigma_{i} p_{i} \ln$ $\left(p_{i}\right)$. If only one play is performed, entropy is 0 , which is the lowest it can be (there is neither diversity nor surprise), and when all $N$ plays are performed equally frequently, 
entropy is maximal at $\ln (N)$. Here I use the exponential of entropy, which then ranges from 1 to $N$ and makes it comparable to the simple number of plays.

Figure 21 shows that, until 1750, relative entropy was fairly high given the number of plays, suggesting that plays were performed relatively equally, and after 1750 it rose along with the number of plays. Mlle Clairon's dictum suggests that the concurrent rise in revenues may not be a pure coincidence. The figure also plots another measure of diversity, namely, the smallest number of plays that account for half of performances. Until 1750 about a quarter of plays accounted for half of performances, but that fraction grew to almost a third by the 1780s, confirming the increasing diversity. Finally, the figure also plots the number of performances for the longest run in each season. The point of this statistic is to explain some of the abrupt year-to-year variations in the measure of entropy. Entropy falls when one play has a particularly long run, decreasing diversity. The big spike in 1784 is Beaumarchais's Mariage de Figaro.

Figure 23 hows similar measures, but for authors. Diversity in authors had begun to rise a little in the 1740 s, but the trend break around 1750 remains noticeable. 


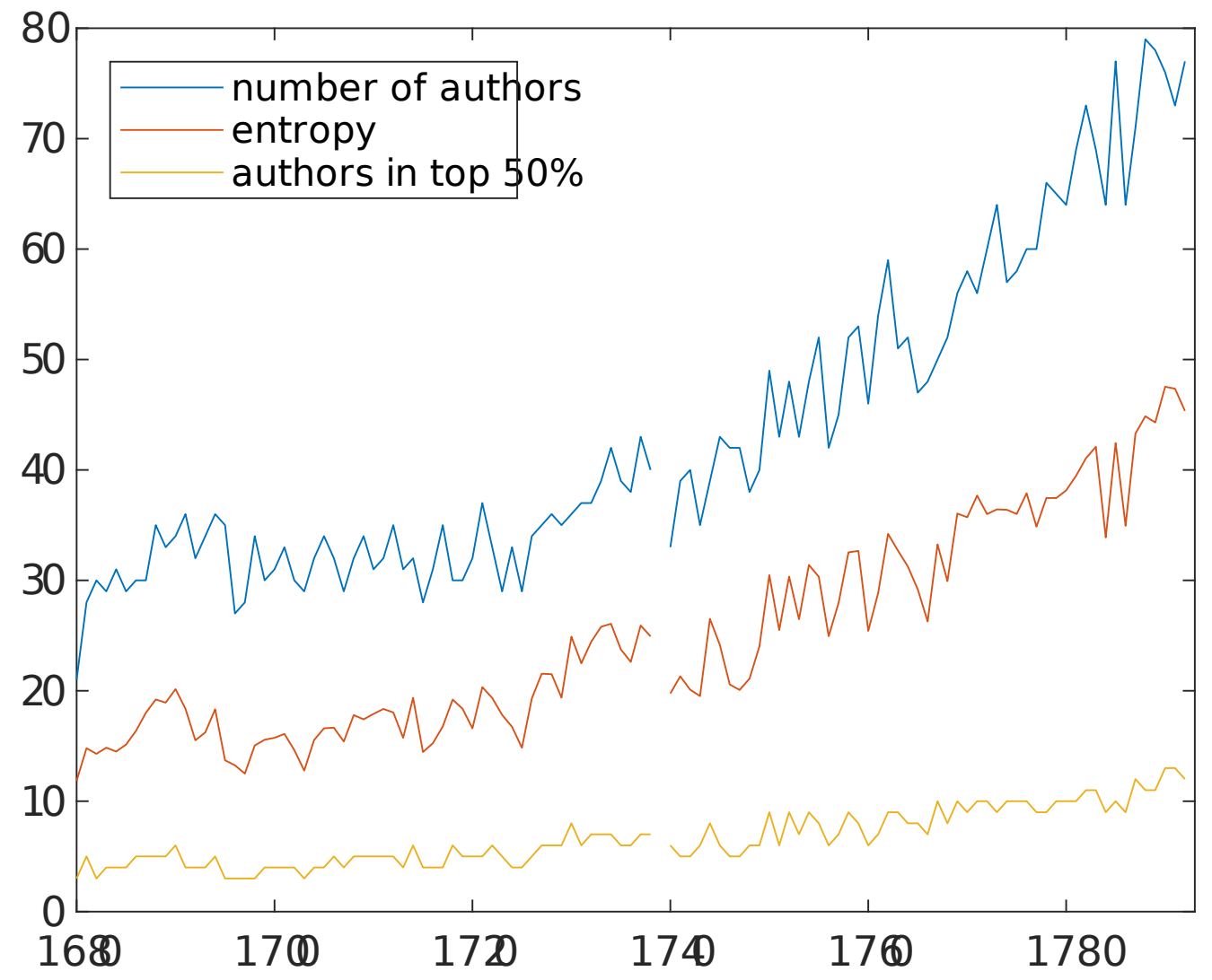

Figure 23. Number of authors, measure of diversity, number of authors representing the top 50\% performances, 1680-1792.

\subsection{Novelty}

The Comédie-Française, from its inception, was in large part devoted to the preservation of a literary legacy, that of the 17 th century. Did this change over time, and were new works added to the canon? 


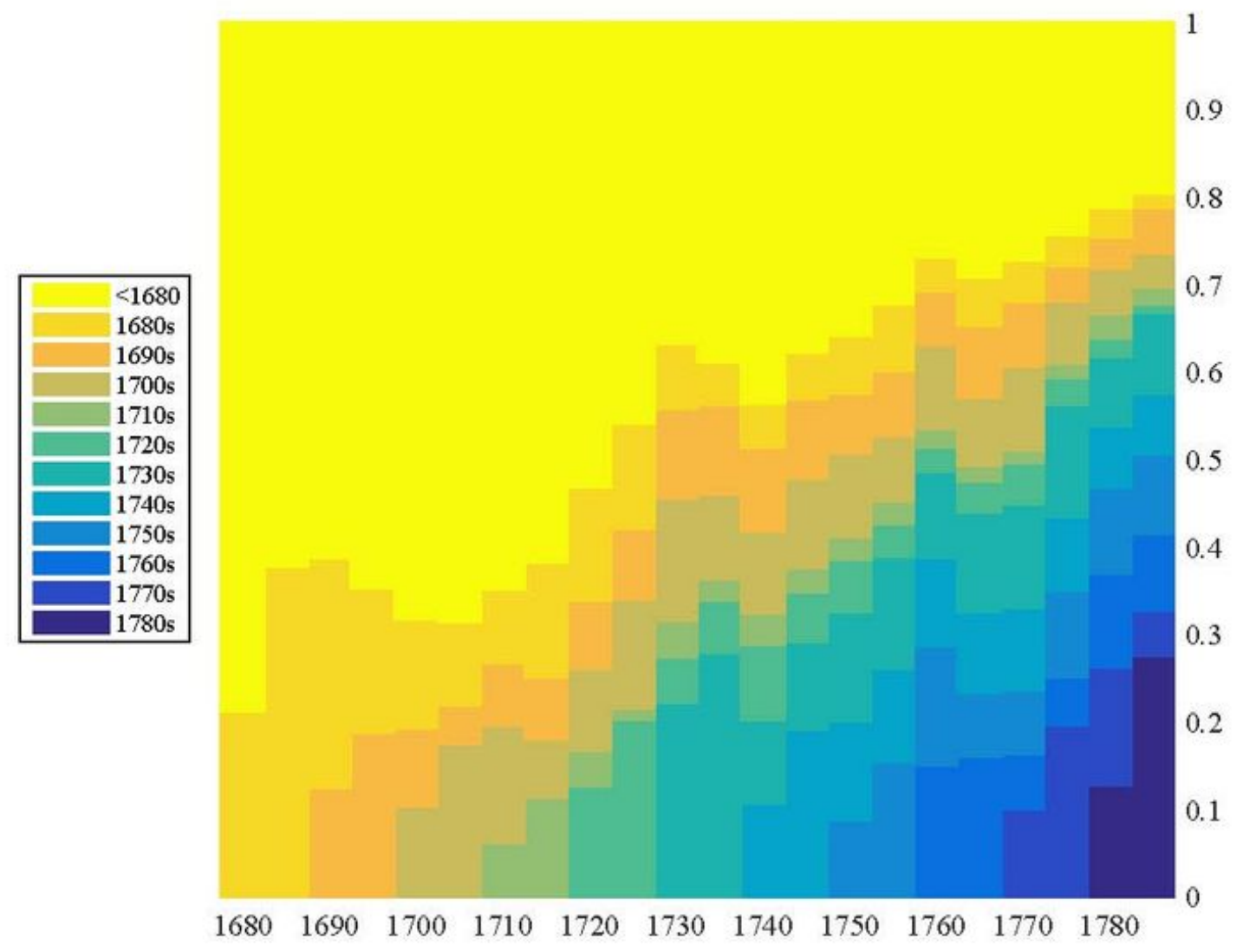

Figure 24. Shares of performances by decade of creation of plays.

Figure 24 shows the share of performances accounted for by plays created in different decades; the shares are calculated by half-decades. At the left of the graph, one sees that the vast majority of plays belonged to the "classical" (pre-1680) repertoire, as had to be the case. Over time new plays are introduced, and the share of classics shrinks, but it stabilizes quickly in the 1690s, and even increases its share. It shrinks again in the 1720 s but stabilizes again in the 1730s, as new plays have difficulty maintaining their share after 10 or 15 years. This changes somewhat after 1750. In particular, the vintages of the 1730s, 1750s and (to a lesser extent) 1760s remain entrenched in the repertory. 


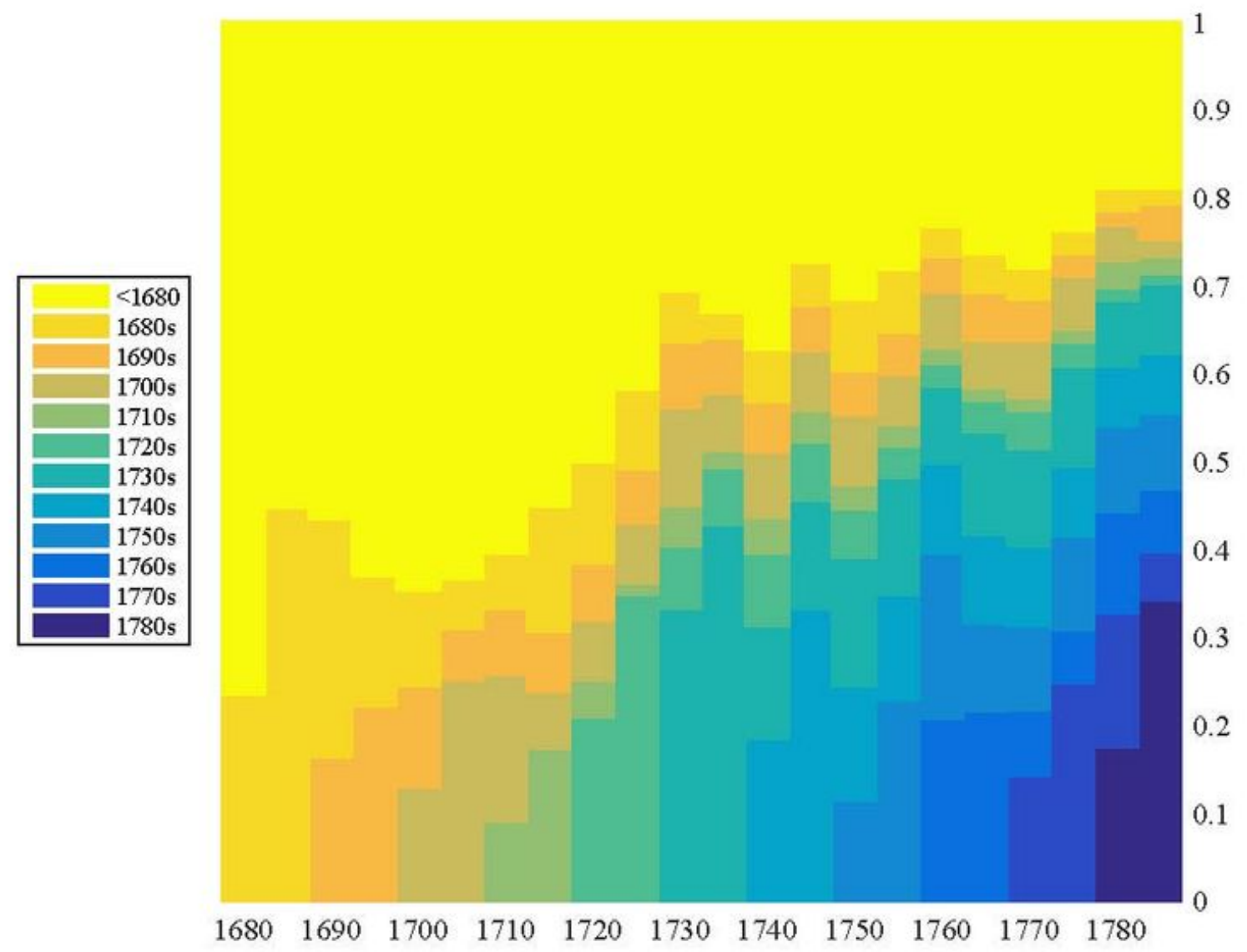

Figure 25. Shares of audiences by decade of creation of plays.

Figure 25 shows in a similar way the share of audiences (that is, of total tickets sold) by vintage. The picture is broadly similar, but the overall decline of classics is even starker. 


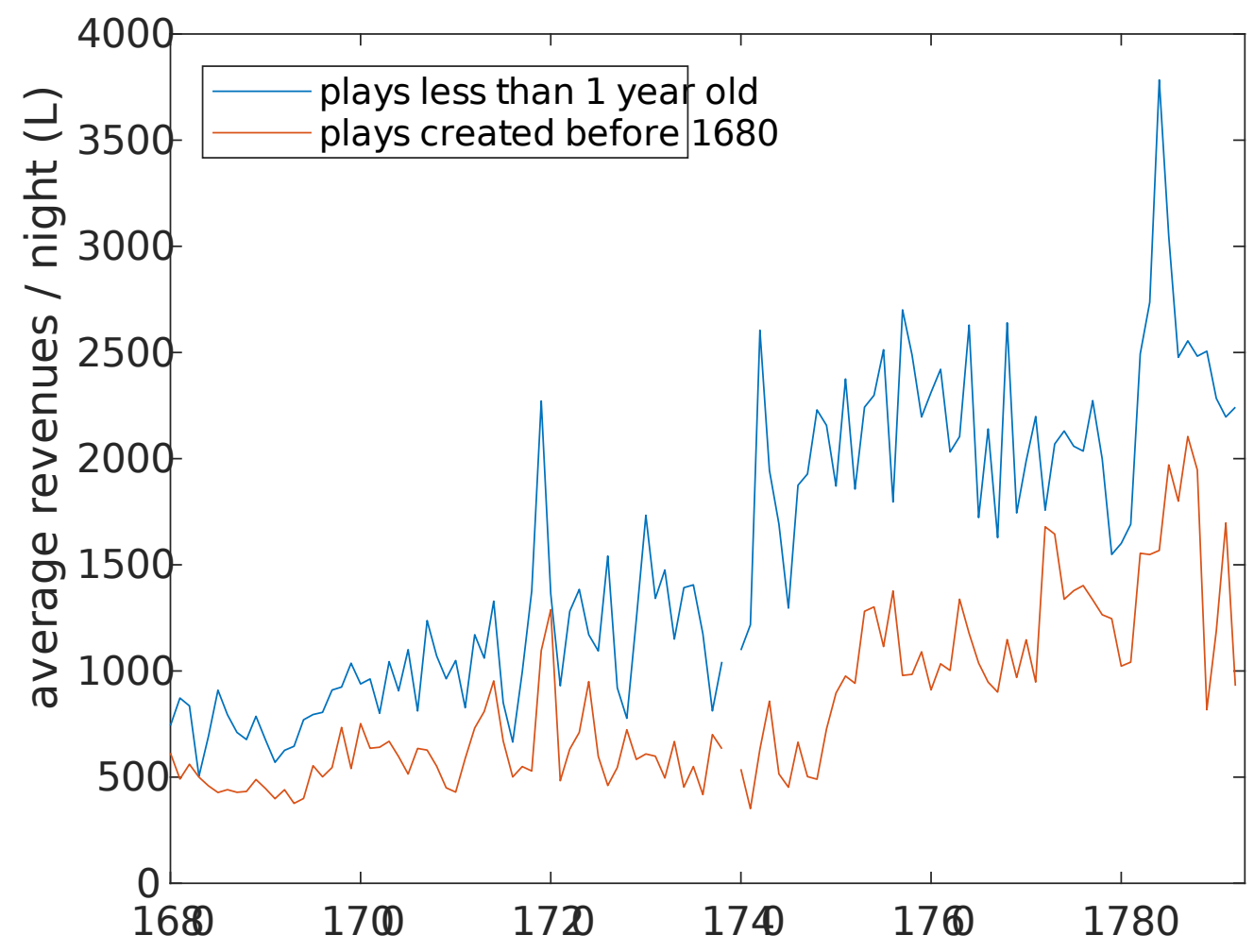

Figure 26. Average daily revenues of "classics" and "novelties."

The next two figures show the relation between age and revenues. The two categories plotted are novelties (plays less than old year old) and "classics". Revenues per night [Fig. 26] was stable for classics at around $500 \mathrm{~L}$ and fluctuated modestly. It increased in step with the general increase in revenues after 1748. Revenues for novelties were more volatile (about 40\%, adjusting for the common trend) and rose more than revenues of classics. 


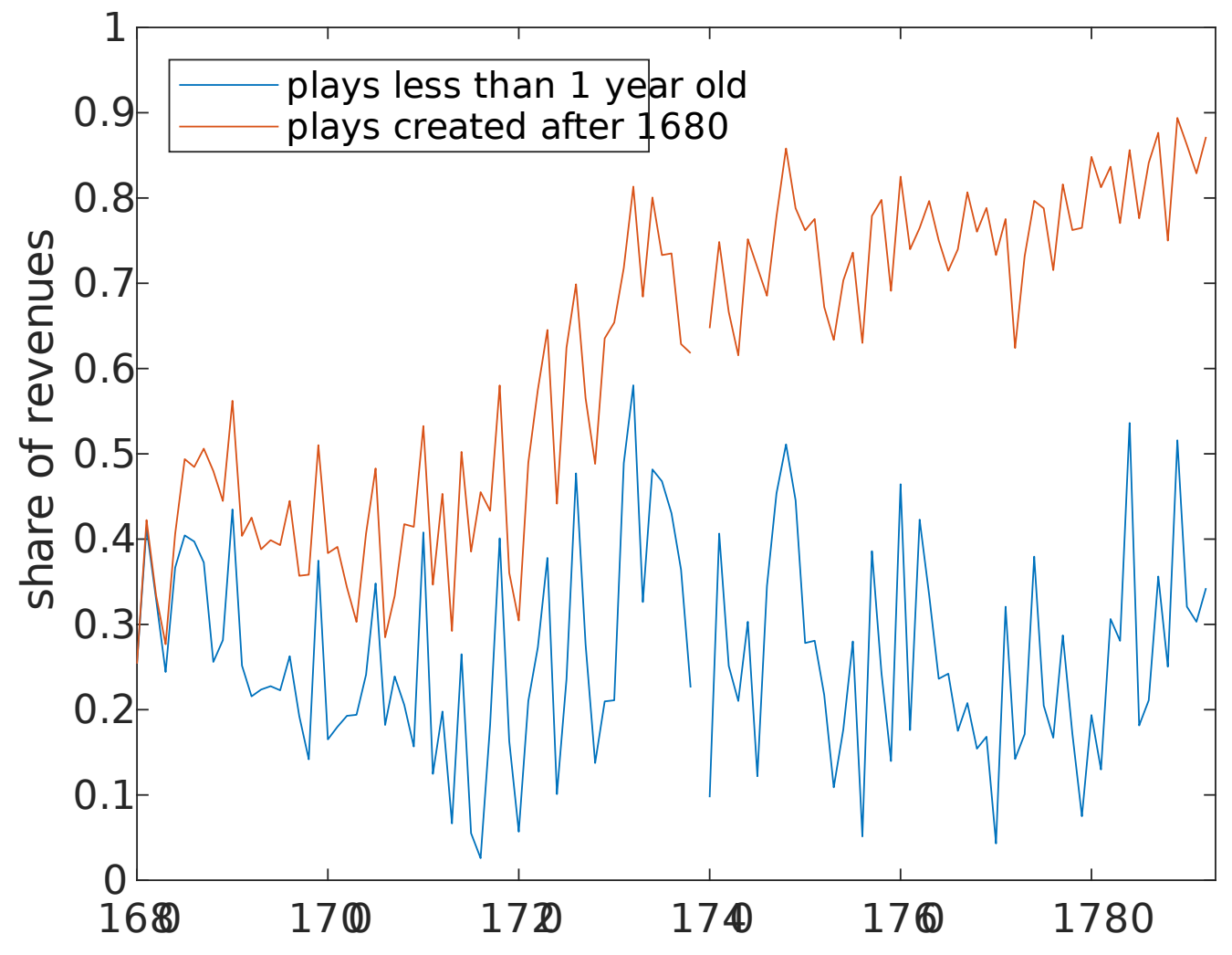

Figure 27. Share of revenues of "classics" and "novelties."

Shares of total revenues are plotted in Figure 27. To make the graph more readable the share of plays created after 1680 is plotted: the share of classics is simply 1 less that share. The share of classics stabilized early on at $40 \%$, then declined from 1720 to 1735 and stabilized again, drifting down to less than $20 \%$ by the end of the period. The share of novelties is much more volatile and rises considerably after 1780 .

\subsection{Variability}

The final set of figures represent the characteristics of the attendance figures, distinguishing by the vintage of the plays performed. $\underline{61}$

Until the 1740s the pattern of mean attendance is as follows. The classics (pre-1680 plays) had a relatively stable attendance. New plays typically began with higher mean attendance, and this initial mean increased over time. But for each vintage the pattern is the same: after the first decade, mean attendance declines quickly to about the same level as that of classics. New plays on average do well, but their attraction declines fairly rapidly, although it does not fall below classics. The initial variability of attendance for new plays is relatively constant over time; and for each vintage, 
variability declines quickly. This is consistent with a selection mechanism: the new plays that are kept are no worse than the classics in the repertoire, and there is less uncertainty about attendance for those plays that are selected to remain in the repertoire.

After 1740, the pattern changes. There is a step increase in mean attendance both for classics and new plays. Although initial mean attendance continues to grow over time (except for the vintages of the 1730s and 1760s), some vintages (1730s and 1740s) do not experience as much of a decline in ensuing decades. Furthermore some old vintages (1690s, 1710s) decline even below the classics, which seem to gain increased favor. For variability, the 1730 s and 1740 vintages also stand out because they do not experience the same decline in uncertainty. The last two decades of attendance, the 1770s and 1780s, show the impact of change in venues: attendances are compressed in the 1770s and expand with the move to the new theater in 1782, as we saw earlier. This suggests, at a minimum, that the 1740s and 1750s were a period of change in tastes, and that the Comédie-Française had difficulty in adjusting its programming strategy to the new realities. 


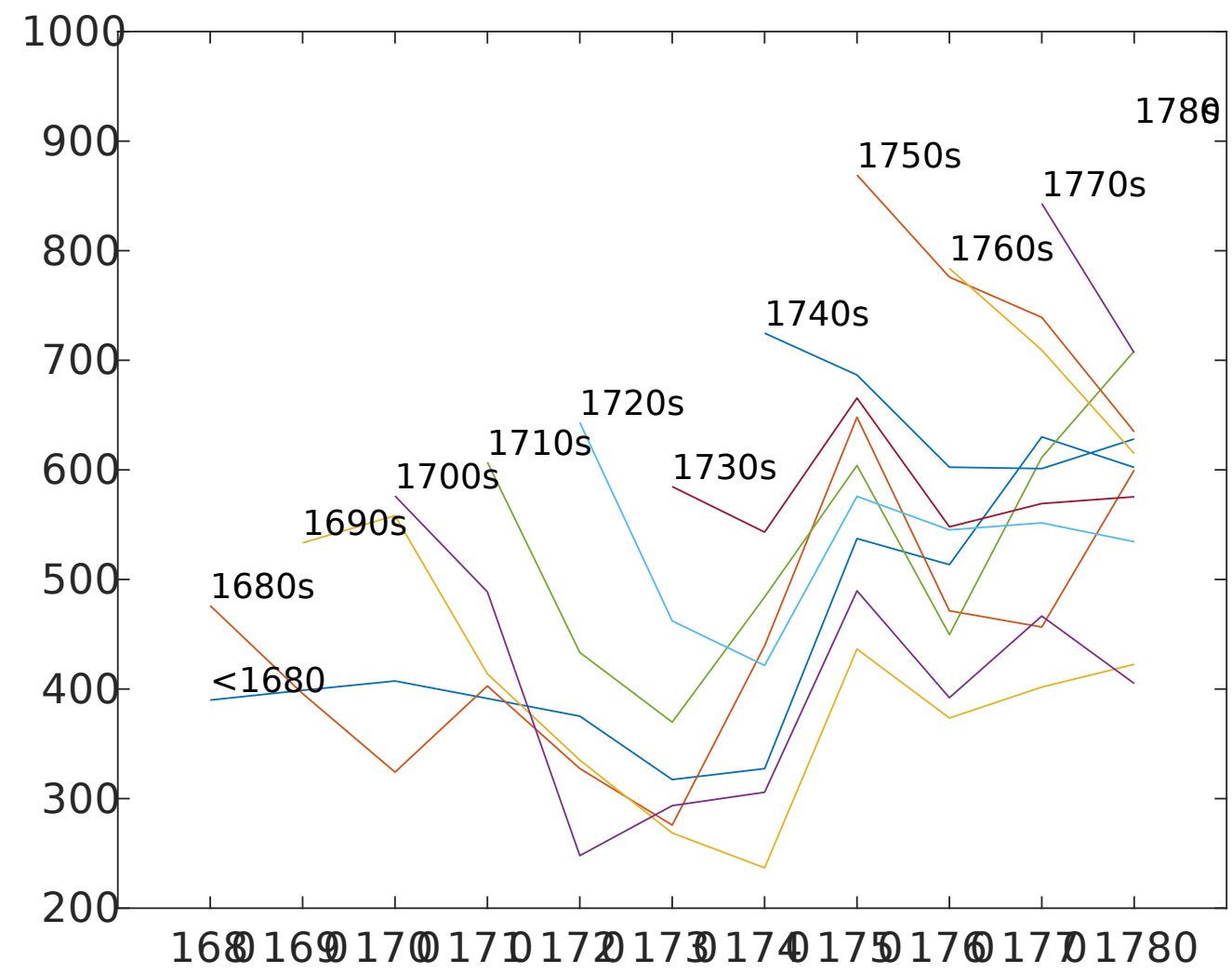

Figure 28. Mean attendances per session by decade and vintage of plays. 


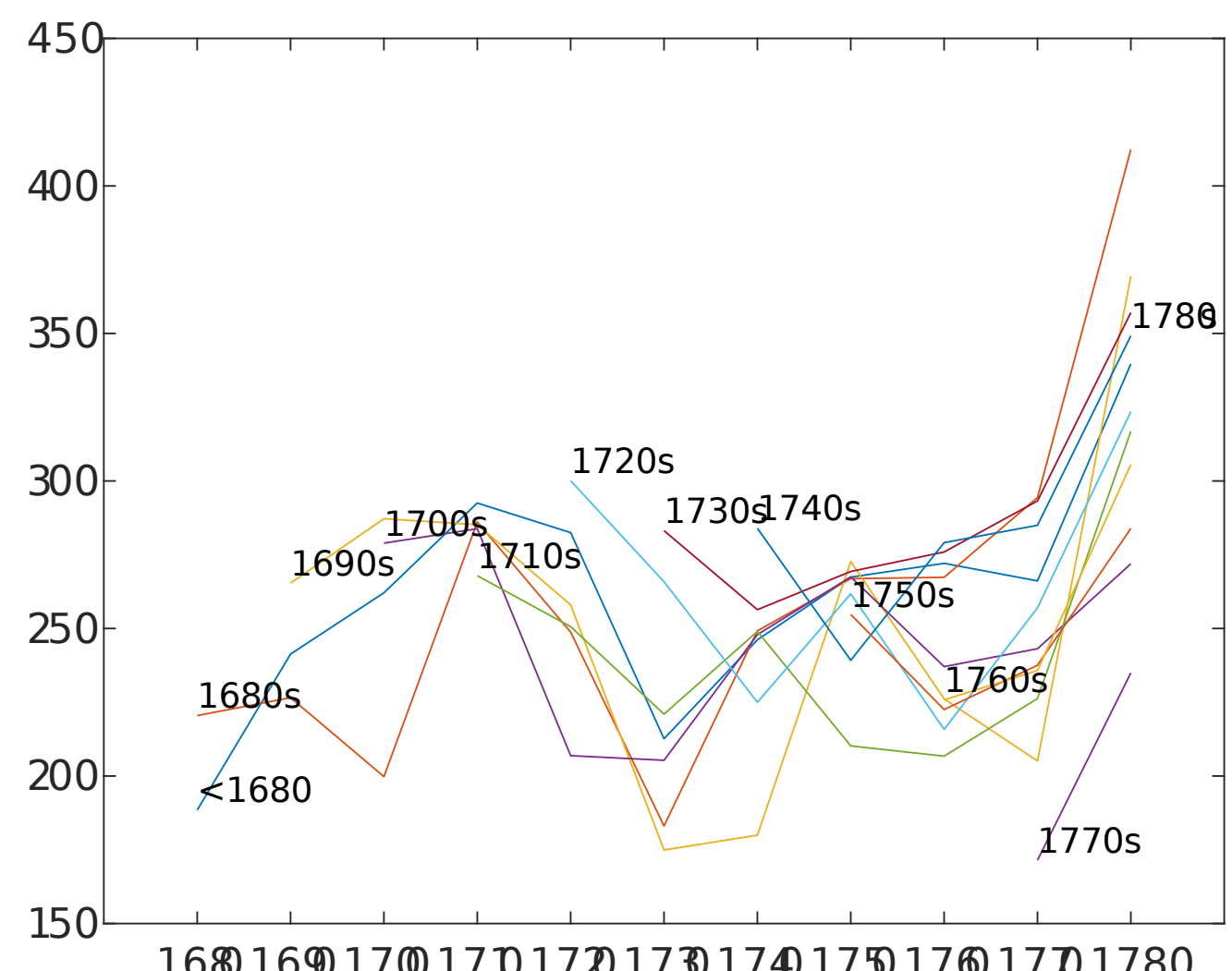

Figure 29. Standard deviation of attendances per session by decade and vintage of plays.

\section{(Provisional) Conclusion}

Most of this paper has consisted in plotting and commenting data. This was possible only because of the extraordinary resource offered by the $\underline{\mathrm{CFRP}}$.

There are limits to the conclusions that can be drawn without further analysis, because the data we observe is the result of an interaction between audiences' tastes and the programming choices of the actors. Nevertheless, some conclusions can be tentatively drawn.

The Comédie-Française operated as a business in a concentrated entertainment industry, with three established incumbents and a competitive fringe; the importance of the latter grew after the 1760s. The competition with the Opéra appears in the weekly pattern of daily revenues and attendance, and in the pricing strategy that the Comédie-Française followed. The business was risky: variability in attendance was enormous. 
The Comédie-Française, run by and for the actors, had a range of tools at its disposal, from seating configuration to pricing and selection of plays performed. It enjoyed a fair amount of freedom in the use of these tools, subject to some overall constraints imposed by the supervising authority.

Despite ongoing and increased competition, revenues grew in the second half of the 18 th century, with a sharp jump after 1748. The Comédie-Française was not the only beneficiary, as the two other main players also saw their revenues increase in a similar fashion.

The increase seems to be in step, but is not explained away by inflation; attendance figures display the same break in 1748. Rather, it seems possible that it was a change in the income of theater-goers that was perhaps related to (grain and land) inflation.

The Comédie-Française had a great deal of freedom in its pricing strategies. They changed over time in a variety of ways. Initially tied to the pattern of coinage, the price schedules became untethered during the monetary disturbances of 1690-1715, and ceased to respond to devaluations. They did respond to the inflation of 1720, however. The Comédie-Française moved from charging premia for special events to offering discount for specific days, and eventually adopting constant pricing after it moved to a new venue. Prices increased after 1753 and new pricing strategies were devised for renting boxes, which at the same time became available in a variety of configurations and locations. But these price increases took place after the increase in attendance.

In terms of repertory, the Comédie-Française operated a selection mechanism, relying on a repertory of proven classics and adding novelties that did at least as well; it thus tried to learn about the demand for its products. The Comédie-Française took care to provide a wide variety of offerings to its public, and this variety was also sharply increased from 1750 onward. A mid-18th century break can also be found in the choice between classics and novelty, with diminished reliance on classics and a younger repertory.

The break in 1748 possibly came about from a change in audience demand, and it may have taken the Comédie-Française a while to adapt to the new realities.

The next step is to investigate empirically the determinants of programming choices and, if possible, model the Comédie-Française's programming strategy. 


\section{Appendix 1: gold and silver coins}

\begin{tabular}{|c|c|c|c|c|c|c|c|c|c|c|c|c|c|c|}
\hline \multirow[t]{2}{*}{ year } & \multicolumn{14}{|c|}{ fraction } \\
\hline & 1 & $\frac{1}{2}$ & $\frac{1}{3}$ & $\frac{1}{4}$ & $\frac{1}{5}$ & $\frac{1}{6}$ & $\frac{1}{8}$ & $\frac{1}{10}$ & $\frac{1}{12}$ & $\frac{1}{16}$ & $\frac{1}{20}$ & $4 \mathrm{~s}$ & $\frac{1}{24}$ & $2 s$ \\
\hline 1679 & 3 & 1.5 & & 0.75 & & & & & 0.25 & & & 02 & 0.125 & 0.1 \\
\hline \multirow[t]{2}{*}{1689} & 33 & 1.65 & & 0.825 & & & & & & & & 0.2 & & \\
\hline & lowe & ed to 3. & U ul. & 692-Aug & 693) & & & & & & & & & \\
\hline \multirow[t]{2}{*}{1693} & 3.6 & 1.8 & & 0.9 & & & & & 0.3 & & & & & \\
\hline & lowe & ed to 3.2 & $5(J a n$ & 1700-Ju & (701) & & & & & & & & & \\
\hline \multirow[t]{2}{*}{1701} & 3.8 & 1.9 & & 0.95 & & & & & 0.317 & 0.25 & & & & \\
\hline & lowe & ed to 3. & (Sep & 702-No & (703) & & & & & & & & & \\
\hline \multirow[t]{2}{*}{1704} & 4 & 2 & & 1 & & & 0.5 & & 0.333 & & & 0.3 & & \\
\hline & lowe & ed to 3. & $5(A P$ & $1705-N$ & $r 709$ & & & & & & & & & \\
\hline \multirow[t]{2}{*}{$17 \oplus$} & 5 & 25 & & 1.5 & 1 & & & 0.5 & & & 0.5 & 02 & 0.125 & \\
\hline & lowe & ed to 3.5 & (Dec & 713-Sep & .715) & & & & & & & & & \\
\hline 1715 & 5 & 2.5 & & 1.25 & & & & 0.5 & & & 0.25 & & & \\
\hline \multirow[t]{2}{*}{1718} & 6 & 3 & & 1.5 & & 1 & & 0.6 & 0.5 & & & & & \\
\hline & lowe & ed to 5.6 & (Sep & 719-Dec & (719) & & & & & & & & & \\
\hline \multirow[t]{2}{*}{1720} & 9 & 4.5 & 3 & & & 15 & & & 0.75 & & & & & \\
\hline & lowe & ed to 7.5 & (Dec & 720), 6. & (Aug 1 & 723), 4 & 1724) & & & & & & & \\
\hline \multirow[t]{2}{*}{1724} & 4 & 2 & & 1 & & & 0.5 & & & 0.25 & & & & \\
\hline & lowe & d to 3 & $e b 1)$ & & & & & & & & & & & \\
\hline \multirow[t]{2}{*}{176} & 5 & 2.5 & & & 1 & & & 0.5 & & & 0.25 & & & \\
\hline & rais & I to $6 \mathrm{LO}$ & 1 & & & & & & & & & & & \\
\hline 1726 & 6 & 3 & & & 1.2 & & & 0.6 & & & 0.3 & & & \\
\hline
\end{tabular}

Table 5. The silver écu, its fractions, and their face values, 1679-1726. 
Databases, Revenues, \& Repertory: The French Stage Online, 1680-1793 • Databases, An Analysis of Revenues at the Comédie-Française, 1680-1793

\begin{tabular}{|c|c|c|c|}
\hline \multirow[t]{2}{*}{ year } & \multicolumn{3}{|c|}{ fraction } \\
\hline & 2 & 1 & $\frac{1}{2}$ \\
\hline 1679 & 22 & raised to 11.5 (Ju I 1686), 11.25 (Oct 1687 & $\begin{array}{l}5.5 \\
11.5 \text { (Ju / 1686), } 11.25 \text { (Oct 1687) }\end{array}$ \\
\hline 1689 & 25 & $\begin{array}{l}12.5 \\
\text { lowere }\end{array}$ & $\begin{array}{l}6.25 \\
11.5 \text { (Apr 1692-Aug 1693) }\end{array}$ \\
\hline 1693 & 28 & \multicolumn{2}{|c|}{ lowered to 12 (J an 1700-J ul 1701) } \\
\hline 1701 & 28 & lowered to 13 (Sep 1702-Nov 1703) & $\begin{array}{l}7 \\
13 \text { (Sep 1702-Nov 1703) }\end{array}$ \\
\hline 1704 & 30 & $\begin{array}{l}15 \\
\text { lowere }\end{array}$ & $\begin{array}{l}7.5 \\
12.5(\text { Apr 1705-Mar 1709) }\end{array}$ \\
\hline 1709 & 40 & $\begin{array}{l}20 \\
\text { lowere }\end{array}$ & $\begin{array}{l}10 \\
14 \text { (Dec 1713-Sep 1715) }\end{array}$ \\
\hline 1715 & 40 & 20 & 10 \\
\hline 1716 & 30 & 15 & 7.5 \\
\hline 1718 & & \multicolumn{2}{|c|}{ lowered to 32 (May 1719-Dec 1719) } \\
\hline 1720 & & \multicolumn{2}{|c|}{ lowered to 45 (Dec 1720) } \\
\hline 1723 & 54 & \multicolumn{2}{|c|}{ lowered to 16 (1724), 12 (Feb 1726) } \\
\hline 1726 & 40 & 20 & 10 \\
\hline 1726 & 48 & 24 & 12 \\
\hline
\end{tabular}

Table 6. The gold louis, its fractions, and their face values, 1679-1726. 


\section{Appendix 2: pricing schedules}

\begin{tabular}{|c|c|c|c|c|c|c|c|c|c|}
\hline \multicolumn{4}{|c|}{ regular pricing } & \multicolumn{4}{|c|}{ premium pricing } & \multirow{2}{*}{$\frac{\text { occurrences }}{5645}$} & \multirow[t]{2}{*}{ dates and notes } \\
\hline 3 & 1.5 & 1 & 0.75 & & & & & & \\
\hline & & & & 5.5 & 3 & 1.5 & 1.5 & 128 & $1680-$ Mar 1686 \\
\hline & & & & 5.5 & 3 & 1.5 & 0.75 & 11 & Nov 1681 - Feb 1682 \\
\hline & & & & 9 & 3 & 1.5 & 1.5 & 1 & 23 Feb 1681 \\
\hline & & & & 11 & 3 & 1.5 & 0.75 & 1 & $28 \operatorname{Dec} 1681$ \\
\hline & & & & 5.75 & 3 & 1.5 & 1.5 & 16 & Nov 1686 - Mar 1687 \\
\hline & & & & 5.5 & 3 & 1.5 & 1.5 & 4 & Dec 1686 - Jan 1687 \\
\hline & & & & 5.625 & 3 & 1.5 & 1.5 & 18 & Nov 1687 - J an 1688 \\
\hline & & & & 5.625 & 3 & 1.5 & 1.5 & 14 & Nov 1688 - Feb 1689 \\
\hline & & & & 5.625 & 3 & 1.5 & 1.5 & 3 & Dec 1689 \\
\hline \multirow[t]{3}{*}{3.1} & 1.55 & 1.05 & 0.775 & & & & & 17 & Dec 1689 \\
\hline & & & & 5.5 & 3 & 1.5 & 1.5 & 45 & Ja n 1690 - Feb 1695 \\
\hline & & & & 5.5 & 3 & 2 & 1.5 & 1 & 5 Feb 1696, visit of Dauphin \\
\hline \multirow[t]{2}{*}{5.5} & 1.5 & 1 & 0.75 & & & & & 1 & 12 Dec 1696, premiere of Polimneste \\
\hline & & & & 5.5 & 3 & 1.5 & 1.5 & 2 & Ja n 1699 \\
\hline
\end{tabular}

Table 7. Pricing schedules, 1680-99. 


\begin{tabular}{|c|c|c|c|c|c|c|c|c|c|}
\hline \multirow[b]{2}{*}{3.6} & \multicolumn{3}{|c|}{ regulapricing } & \multicolumn{3}{|c|}{ premiunpricing } & \multirow{2}{*}{\multicolumn{2}{|c|}{$\begin{array}{r}\text { occurreces } \\
4486\end{array}$}} & \multirow[t]{2}{*}{ dates andnotes } \\
\hline & 1.8 & 1.2 & 0.9 & & & & & & \\
\hline 3.55 & 1.775 & 1.2 & 0.8875 & & & & & 28 & Jan 1700 \\
\hline 3.5 & 1.775 & 1.2 & 0.8875 & & & & & 1 & 1 Feb 1700 \\
\hline 3.5 & 1.75 & 1.2 & 0.875 & & & & & 52 & Feb-Mar 1700 \\
\hline 3.45 & 1.725 & 1.2 & 0.8625 & & & & & 41 & Apr-May 1700 \\
\hline 3.4 & 1.7 & 1.2 & 0.85 & & & & & 206 & Jun-Dec 1700 \\
\hline 3.35 & 1.675 & 1.2 & 0.8375 & & & & & 68 & J an - Mar 1701 \\
\hline 3.3 & 1.65 & 1.2 & 0.825 & & & & & 57 & Apr-J un 1701 \\
\hline 3.25 & 1.625 & 1.2 & 0.8125 & & & & & 55 & Jul - Sep 1701 \\
\hline \multirow[t]{9}{*}{3.2} & 1.6 & 1.2 & 0.8 & & & & & 3 & Jul 1701 \\
\hline & & & & 7.2 & 3.6 & 2.4 & 1.8 & 26 & J un - J ul 1703, Aug 1705 revivals of Psichéand Circé \\
\hline & & & & 7.2 & 3.6 & 2.4 & 1.8 & 1 & 180ct1706, visitofJamesll \\
\hline & & & & 7.2 & 3.6 & 1.2 & 0.9 & 1 & 1707 closing \\
\hline & & & & 7.2 & 3.6 & 2.4 & 1.8 & 1 & 17 Nov 1709 visit of Elector of Bavara \\
\hline & & & & 7.2 & 3.6 & 1.8 & 1.2 & 1 & 18Feb 1710, Baron père in /e/ aloux \\
\hline & & & & 7.2 & 3.6 & 1.2 & 0.9 & 1 & 1710 closure \\
\hline & & & & 7.2 & 5 & 1.8 & 0.9 & 1 & 1711 closing \\
\hline & & & & 7.5 & 3.6 & 2.4 & 1.8 & 1 & 1713 closing \\
\hline 3.6 & 1.8 & 1.2125 & 0.9 & & & & & 5 & Dec 1713 \\
\hline 3.5625 & 1.875 & 1.1875 & 0.9 & & & & & 31 & Feb-Mar 1714 \\
\hline 4.875 & 1.9375 & 1.2 & 0.9 & & & & & 4 & Feb 1715 \\
\hline 3.875 & 1.9375 & 1.2 & 0.9 & & & & & 32 & Mar 1715 \\
\hline 3.75 & 1.875 & 1.2 & 0.9 & & & & & 37 & Apr-May 1715 \\
\hline 3.625 & 1.8125 & 1.2 & 0.9 & & & & & 86 & Jun-Aug1715 \\
\hline \multirow[t]{4}{*}{3.625} & 1.8 & 1.2 & 0.9 & & & & & 1 & 25 Apr 1714 \\
\hline & & & & 7.125 & 3.5625 & 2.375 & 1.8 & 1 & 1714 closing \\
\hline & & & & 7.2 & 3.6 & 2.4 & 1.8 & 1 & 26 Dec 1714, Polyeucte \\
\hline & & & & 7.5 & 3.75 & 2.4 & 1.875 & 1 & 1715 closing \\
\hline 4 & 2 & 1.2 & 1 & & & & & 1 & 23 Dec 1715, Tartuffe \\
\hline
\end{tabular}

Table 8. Pricing schedules, 1699-1716. 


\begin{tabular}{|c|c|c|c|c|c|c|c|c|c|}
\hline \multicolumn{4}{|c|}{ regular pricing } & \multicolumn{3}{|c|}{ premiumpricing } & \multirow{2}{*}{\multicolumn{2}{|c|}{$\begin{array}{r}\text { occurreces } \\
1640\end{array}$}} & \multirow[t]{2}{*}{ dates andnotes } \\
\hline 4 & 2 & 1.5 & 1 & & & & & & \\
\hline 4 & 2 & 1.4 & 1 & & & & & 24 & Feb 1716 \\
\hline 5 & 2.5 & 1.5 & 1 & & & & & 12 & Mar 1716 \\
\hline 5 & 4 & 2.5 & 1.25 & & & & & 1 & 2 Mar 1716, visitof duchess of Berry \\
\hline \multirow[t]{4}{*}{5} & 3 & 2 & 1.25 & & & & & 2 & Mar 1716, Athalie \\
\hline & & & & 7.5 & 4 & 2.5 & 2 & 1 & 28Mar1716, Polyeucte \\
\hline & & & & 8 & 4 & 3 & 1.5 & 1 & 1719 closing \\
\hline & & & & 5.6 & 2.8 & 2 & 1.5 & 1 & 23Dec 1719, Polyeucte \\
\hline \multirow[t]{5}{*}{4} & 2 & 1.5 & 1 & & & & & 20 & $\operatorname{Jan} 1720$ \\
\hline & & & & 5.6 & 3 & 2 & 2 & 1 & $6 \mathrm{~J}$ an 1720 , le J oueur \\
\hline & & & & 5.6 & 3 & 2 & 1 & 1 & 7J an 1720 \\
\hline & & & & 5.6 & 3 & 2 & 1.5 & 1 & 21Jan 1720 le Cid \\
\hline & & & & 6 & 3 & 2 & 2 & 1 & 24J an 1720 \\
\hline & & & & 6 & 3 & 2 & 1.5 & 1 & 28J an 1720 \\
\hline \multirow[t]{3}{*}{4} & 3 & 2 & 1 & & & & & 106 & Feb-Aug 1720 \\
\hline & & & & 5.675 & 3 & 2 & 1.5 & 15 & 29Jan - Feb 1720 \\
\hline & & & & 8 & 4 & 3 & 2 & 64 & Feb-Aug 1720 \\
\hline \multirow[t]{4}{*}{6} & 3 & 2 & 1.5 & & & & & 29 & Aug-Sep1720 \\
\hline & & & & 8 & 4 & 3 & 2 & 25 & Aug-Sep 1720 \\
\hline & & & & 7.5 & 3.75 & 2.5 & 2 & 2 & 5 Oct 1720 \\
\hline & & & & 7.5 & 3.75 & 2.5 & 2 & 1 & 7 Oct 1720 \\
\hline \multirow[t]{6}{*}{5} & 2.5 & 1.5 & 1.25 & & & & & 140 & Oct1720-Apr1721 \\
\hline & & & & 7.5 & 5 & - & 2.5 & 1 & 22 Oct 1721, Cartouche \\
\hline & & & & 7.5 & 5 & 2.5 & 2.5 & 1 & 1721 closing \\
\hline & & & & 5 & 2.5 & 2 & 1.25 & 1 & 1722 closing \\
\hline & & & & 10 & 5 & - & 2.5 & 1 & $22 \mathrm{Feb} 1723$ \\
\hline & & & & 5 & 2.5 & - & 1.25 & 1 & 1723 closing \\
\hline
\end{tabular}

Table 9. Pricing schedules, 1716-23. 


\begin{tabular}{|c|c|c|c|c|c|c|c|c|c|}
\hline \multicolumn{4}{|c|}{ regularpricing } & \multicolumn{4}{|c|}{ premiumpricing } & \multirow{2}{*}{$\begin{array}{r}\text { occurreces } \\
8482\end{array}$} & \multirow[t]{2}{*}{ dates andnotes } \\
\hline 4 & 2 & 1.5 & 1 & & & & & & \\
\hline & & & & 6 & 3 & 2 & 1 & 7770 & \\
\hline & & & & 8 & 4 & 3 & 2 & 1 & 6 Mar1724,premiæe of Marianne \\
\hline & & & & 8 & 4 & 3 & 2 & 3 & $1724,1725,1726$ closings \\
\hline & & & & 8 & 4 & 3 & 1.2 & 1 & 1727 closing \\
\hline & & & & 6 & 3 & 1.8 & 1 & 1 & 1728 closing \\
\hline & & & & 6 & 3 & 1.8 & 1.2 & 1 & 1729 closing \\
\hline & & & & 6 & 2 & 1.5 & 1 & 3 & Feb1730, premiereand2d of Callisthène; 1730closing \\
\hline & & & & 6 & 2 & 1.5 & 1 & 1 & 4 Nov 1730 , premiere of Prince de Noisy \\
\hline & & & & 6 & 3 & 2 & 1 & 7 & Dec 1730, firstrun of Brutus; 1731 closing \\
\hline & & & & 6 & 3 & 1.5 & 1 & 1 & 1731 opening \\
\hline & & & & 6 & 3 & 2 & 1 & 3 & May 1731 ,firstrunof ItalieGalante \\
\hline & & & & 6 & 3 & 1.5 & 1 & 2 & Nov-Dec1731,premieresof Bayard, Erigone \\
\hline & & & & 6 & 2 & 1.5 & 1 & 1 & 19Dec 1731, second of Erigone \\
\hline & & & & 6 & 3 & 1.5 & 1 & 13 & Ja n 1732, first run of le Glorieux \\
\hline & & & & 6 & 3 & 2 & 1 & 4 & Mar1732,fiistrunofEriphille \\
\hline & & & & 6 & 3 & 1.5 & 1 & 1 & 1732 closing \\
\hline
\end{tabular}

Table 10. Pricing schedules, 1723-82.

\section{Footnotes}

1. Other registers contain information about the spending side and overall income, but only from the late 1750s. For this paper I focus on the receipts. 2. In deference to Christian Biet I use this word (séance in French) rather than "night" to designate the events. The performance started at 5:15 pm which, for two thirds of the year, was before sundown. $ヒ$

3. The Chevalier de Mouhy already lists their contents and notes the absence of the register for the 1739-40 season, which is today the only one missing; see Charles de Fieux, Chevalier de Mouhy, Abrégé de l'histoire du théâtre françois, depuis son origine jusqu'au premier juin de l'année 1780 (Paris: L. Jorry, 1780). They were published in abridged version, up to 1774, in Henry Carrington Lancaster, The Comédie-Française, 1701-1774. Plays, Actors, Spectators, Finances (Philadelphia, The American Philosophical Society, 1951).

4. See Claude Alasseur, La Comédie-Française au XVIII $I^{e}$ siècle. Étude économique (Paris: Mouton, 1967); and Henri Lagrave, Le Public et le théâtre à Paris de 1715 à 1750 (Paris, Klincksieck, 1972).

5. So far I have only examined revenues. The expenditures side needs to be investigated, but the archival material is not as complete, as annual accounts are 
available from 1755 only; see Alasseur, La Comédie-Française au XVIII ${ }^{e}$ siècle. $ヒ$ 6. The choice of actors is another variable, but casting lists have not yet been transcribed. $匚$

7. For the Comédie-Italienne, Gallica (gallica.bnf.fr) has digitized the surviving daily registers: seasons 1717, 1721-24, 1728-32, 1735-36, 1740-60, 1763-78, 1780, 1783, 1785-93. For the Opéra, I have used the Manuscrit Ténéo (Bibl. de l'Opéra, D144), which contains total receipts for the seasons 1735, 1743, 1749$52,1756-62$, and from 1764. The Journal de l'Opéra is available from the late 1700s. $\uplus$

8. The work of Jules Bonnassies, La Comédie-Française, histoire administrative, 1658-1757 (Paris: Didier et Cie, 1874) remains essential for the period up to 1757; Bonassies was an archivist of the Comédie-Française. $\_$

9. The text of the lettre de cachet reads: “. . . veut que ladite seule troupe puisse représenter les comédies dans Paris. . ." Bonnassies, La Comédie-Française, histoire administrative, $62 . \pm$

10. The annuity was owed to the retiree by the company itself, not the incoming actor. From 1724 the newly issued annuities included a "non-compete" clause: the annuity was voided if the retiree performed in another Parisian theater. $\bullet$ 11. The amount, assessed in 1692, was 198,233L; it was increased in 1705 to include a tax payment. $\Xi$

12. Before the Revolution gave authors legal rights to royalties for performances of their works in 1791, such payments were negotiated between authors and performers. The traditional methods had been a lump-sum payment or a share of the company's profits for a certain amount of time; in either case the text eventually became the property of the company; see Jules Bonnassies, Les Auteurs dramatiques et la Comédie-Française à Paris aux XVII et XVIII siècles, d'après des documents inédits extraits des archives du Théâtre-Français (Paris: Léon Willem, Paul Daffis, 1874). This system survived until the French Revolution.

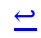

13. I will show later that there was indeed a downward trend in the number of tragedies performed until the mid-18th century. $\bullet$ 
14. Contrary to modern academic journals, only one resubmission was allowed. 15. The ext of the order and the by-laws in Arrests du Conseil d'État (1761) is available at archive.org); the order is also in Mouhy, Abrégé de l'histoire du théâtre françois, 3:47-59. $\uplus$

16. Mouhy, Abrégé de l'histoire du théâtre françois, 3:119-48.

17. See the remark by Bonnassies, Les Auteurs dramatiques et la ComédieFrançaise, 44: "le caractère fantaisiste et indiscipliné des comédiens enfreignait les prescriptions des Supérieurs avec d'autant plus de désinvolture que cette même Supériorité était la première à leur donner l'exemple des infractions." 18. See Bonnassies, La Comédie-Française, histoire administrative, 230, for a list of grants until 1757. In 1743 the king granted 72,000 L on account of lost revenue due to the ongoing war. Capital expenditures were eventually taken over by the king: in 1753 he gave 20,000 L for repairs, in 1770 lent the Tuileries theater for free, and the new theater of 1782 was built by the king. $\subseteq$ 19. See Jules Bonnassies, Les Spectacles forains et la Comédie-Française (Paris, E. Dentu, 1875). $\doteq$

20. Napoleon restored a form of privilege in 1807, with eight Parisian theaters having exclusive rights over certain genres, theatrical and operatic. Full freedom was not restored until 1864. $\doteq$

21. Bonnassies, Les Auteurs dramatiques et la Comédie-Française. $\doteq$ 22. The Monday was known as Quasimodo Monday. If March 25 fell within Holy Week the Feast of the Annunciation was moved to Quasimodo Monday and the season began the following day. Similarly the Feast of the Conception (December 8) was moved one day ahead when it fell on Sunday. In 1760 the start of the season was further delayed by mourning for the king's grandson. $\bullet$ 23. During those holidays and Passiontide, the only available entertainment (from 1725) was the Concert spirituel, a concert of choral and instrumental religious music of great repute. The Saint-Germain fair, protected by (and profitable for) the abbot of Saint-Germain, was allowed to extend its entertainments until the eve of Palm Sunday, one week later than the theaters. For religious holidays in general in 18th-century France, see Noah Shusterman, “The Decline of Religious Holidays in Old Regime France (1642-1789)” French 
History 23-3 (2009), 289-310; and Jean-Yves Grenier, “Temps de travail et fêtes religieuses au XVIII siècle” Revue historique 314 (2012), 609-41.

24. Lagrave, Le Public et le théâtre, 280-99. $\leftrightarrows$

25. Jubilees are occasions of penitence granted by the pope for a variety of reasons: holy year $(1702,1729,1751,1776)$, new pontificate $(1690,1701,1724$, 1759), praying for peace $(1696,1707)$, the French king's return to health (1745), defeating the Turks (1683) (Le Gall 2007). The details were set locally by the archbishop of Paris. The resulting closures could be continuous or, as in the later years, only on Sundays. $\leftrightarrows$

26. The theater closed for deaths of the king, the queen, the queen's parents, the enfants and petits-enfants de France (children and grand-children in male line of a sovereign) and their spouses. $\_$

27. For example, mourning for the Dauphin or heir apparent lasted 30 days in 1711, 22 days in 1765, and only 9 days in 1789. Mourning for other sons and daughters of France lasted 14 days in 1701, 1714, and 1752, but only 6 days in 1759 and 1761 . Royal ordinances of 1716 and 1730 had shortened the duration of mourning for private individuals. $\doteq$

28. There were 32 free performances and 9 benefits (another benefit for the company in 1717 is recorded, but only total receipts are given). Some of these occasions were nevertheless beneficial for the Comédie-Française, to which the king made a grant of 10,000 L on the birth of the Dauphin in 1729 and on his first marriage in 1745, and 9,000 L on his second marriage in 1747. See Bonnasies, La Comédie-Française..., 230. $\Perp$

29. In about 150 cases it is impossible to read the mention, because it was inscribed at the top of the daily receipt sheet of the ensuing day, and when the sheets were bound together into registers the tops were trimmed, sometimes cutting off the mention. $\leftrightarrows$

30. The results are even weaker, with smaller coefficient and smaller R2, when the trend is removed with a HP filter, or if the means before and after 1749 are removed. $\leftrightarrows$

31. The Comédie-Française also sold lifetime personal entry rights, but their use remained limited. $\triangleq$ 
32. The revenues from the boxes come from the Comédie-Française's annual accounts which start in 1761; Alasseur, La Comédie-Française au XVIII ${ }^{e}$ siècle, 142. The sources for the other two theaters are listed in the next footnote. $\subseteq$ 33. Sources for the Comédie-Italienne: the registers of the Opéra-Comique, Bibliothèque de l'Opéra, TH-OC 10-77 (available on Gallica); for the Opéra: AN $\mathrm{AJ} / 13 / 6,8$, 9, 44, O/1/625, O/3/1636; Bibliothèque de l’Opéra, Opéra Arch 18.20, CO 511, mss D.144 (mss. Ténéo). $\doteq$

34. Archives de l'Assistance Publique et des Hôpitaux de Paris (APHP), HD 1438, C6468-6543; published (with some errors) in Gabriel Cros-Mayrevieille, Le Droit des pauvres sur les spectacles en Europe (Paris: Berger-Levrault et Cie, 1889), 41-43.

35. Philip T. Hoffman, David Jacks, Patricia A. Levin, and Peter H. Lindert, "Real Inequality in Europe since 1500" Journal of Economic History 62, no. 2 (June 2002): 322-55. The published indices are adjusted for variations in the silver content of the unit of account. Phil Hoffman was kind enough to provide me the source data so that I could compute nominal indices. $\triangleq$

36. Philip T. Hoffman et al., "Real Inequality in Europe since 1500," 322-355. 37. I reconstructed the expenditures on live entertainment from archival material (APHP, Foss 58, Foss 772, Foss 342, 2M27-2M30, 5M59-5M101). The GDP series is from Maurice Lévy-Leboyer et François Bourguignon, L'Économie française au XIX $X^{e}$ siècle. Analyse macro-économique (Paris: Economica, 1985.) 38. In addition the Comédie-Française performed once a week at the Théâtre du Palais-Royal (the home of the Opéra) from January 1717 to June 1722, either Wednesdays or Thursdays when the Opéra was not performing. At the time the King resided at the Tuileries and the Régent at the Palais-Royal. In November 1722 the court returned to Versailles. In total 238 performances were held there between 1717 and 1723. The maximum attendance was 1198 on December 27, 1719, somewhat higher than the capacity of 1000 estimated in Bonnassies, La Comédie-Française..., 237. $\bullet$

39. Incidental music often featured in performances, but singing would have infringed the Opéra's monopoly. 
40. For comparison, the equivalent British coins were the gold guinea, of same fineness and weighing $8.38 \mathrm{~g}$, worth $21 \mathrm{~s}$ from 1717; and the silver crown, 92.5\% silver, weighing $7.61 \mathrm{~g}$ and worth $5 \mathrm{~s}$. The livre/pound parity was about 24 in the 18th century. $ヒ$

41. Before 1690 the louis d'or (or pistole) was worth $11 \mathrm{~L}$ and the silver écu $3 \mathrm{~L}$; after 1726 the louis d'or was worth $24 \mathrm{~L}$ and the silver écu was $6 \mathrm{~L}$ (the pistole was occasionally used as a unit of account of $10 \mathrm{~L})$.

42. Until 1686 the registers name the type of seats; from the 1686 season they only list categories by price (billets à . . . L).

43. Until 1686 the registers name distinguish the amphithéâtre and the stage seats, but they were frequently charged at the same price as the first boxes. $\bullet$ 44. After 1715 it only appeared for the premieres of Danchet's Roi de Cocagne in 1718, Brie's Héraclides in 1719, the second performance of Cartouche in 1721, La Motte's Edipe in 1721, Crébillon's Pyrrhus in 1726, and a visit by the duc de Lorraine on February 4, 1730.

45. Bonnassies, La Comédie-Française..., 238, cites evidence that the same prices had been charged as early as 1652 at the Hôtel de Bourgogne, one of the Comédie-Française's predecessors. $\_$

46. As discussed in the next section, the prices of whole boxes were also set in terms of gold coins. $\longleftarrow$

47. A number of entries in the registers express prices in terms of louis, e.g., January 7 and February 29, 1688: “loge de trois louis.” $ヒ$

48. The ordinance, dated February 25, imposed the tax from March 1 as a 1/6 levy on sums received for admittance to opera and theater in Paris, for the benefit of the General Hospital of Paris. $\_$

49. Thus, the écu was at $3.8 \mathrm{~L}$ when the 1702 reduction started, at $5 \mathrm{~L}$ for the 1713 reduction, at $4 \mathrm{~L}$ for the 1715 reduction, at $6 \mathrm{~L}$ for the 1719 reduction. Until 1716 the Comédie-Française's price structure was based on a price of $3.6 \mathrm{~L}$ and fractions thereof. $\subseteq$

50. In other work, I have documented how (unannounced) reductions in the face value of coins in 1724 failed to have an impact on market prices. François Velde, 
“Chronicle of a Deflation Unforetold," Journal of Political Economy, vol. 117, n 4 (2009), 591-634. $匚$

51. Until 1730 it was only used (aside from the traditional closing session) for the second performance of Cartouche in 1721, the last performance at the PalaisRoyal in 1723, and the premiere of Voltaire's Mariamne in 1724.

52. There is evidence that the players encountered some resistance from officials on this occasion. The Paris lieutenant of police tried to prevent them from raising prices for the premiere of Eriphille, but they secured from the First Gentleman permission to raise prices for the first twelve performances. In September 1741 the lieutenant of police again reprimanded the players for raising prices at a premiere. They again argued that they had always been free to do so, and showed excerpts from the registers as proof (AN, O/1/849, n. 68). 53. There are twenty sessions in April-July 1723 where only the total for all box rentals is given. $\bullet$

54. The register entry for December 12 has "une loge de 4 louis."

55. The use of the Palais-Royal venue on Wednesdays between 1717 and 1722 complicates matters a bit, besides introducing new terms like balcon; apparently there were also boxes of six and twelve, on both levels. The box capacity (rarely mentioned) can be inferred by comparing the price of the box to the single ticket. Only the boxes at $48 \mathrm{~L}$ are problematic, because they could be upper boxes of twelve or lower boxes of six, but there are only a few instances. When the number of boxes rented was more than two I assumed that they were upper boxes. $\subseteq$

56. Lagrave, Le Public et le théâtre, 80.

57. See Jeffrey S. Ravel, The Contested Parterre. Public Theater and French

Political Culture, 1680- 1791 (Ithaca, NY: Cornell University Press, 1999), 35. 58. See Sabine Chaouche, La Mise en scène du répertoire à la Comédie-

Française, 1680-1815 (Paris: Honoré Champion, 2013), chap. $3 . \subseteq$

59. The principle that the actors as a group decided on programming goes as far back as 1684; Bonnassies, La Comédie-Française..., 81. 
60. Rules imposed by the First Gentlemen of the Bedchamber, for example, required alternation of comedies and tragedies; they also required at least that one long play and one short play not performed before in the season be staged every month. $\_$

61. The sessions typically included two plays; only the first play's age is taken into account here. $\_$ 